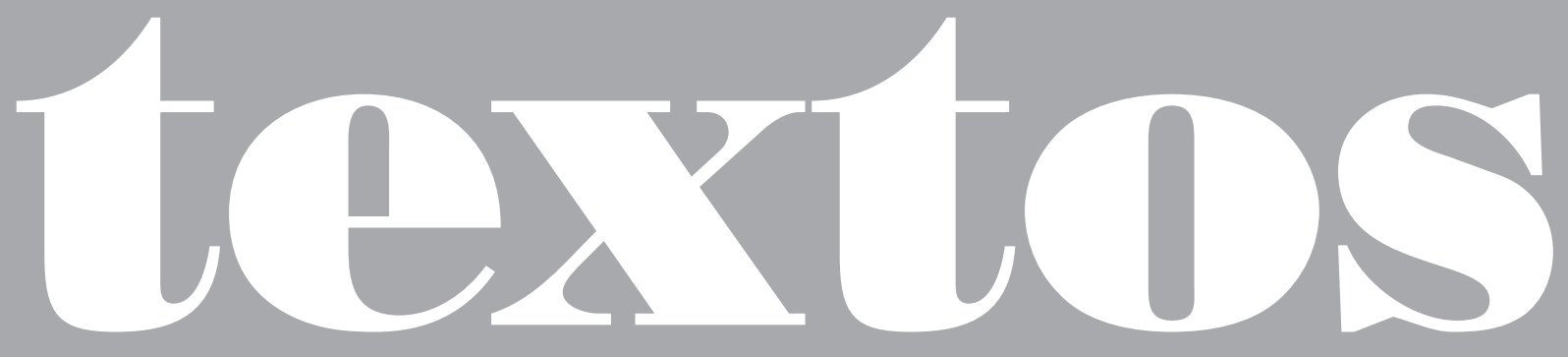





\title{
O mistério dos daguerreótipos do Largo do Paço
}

\author{
Boris Kossoy
}

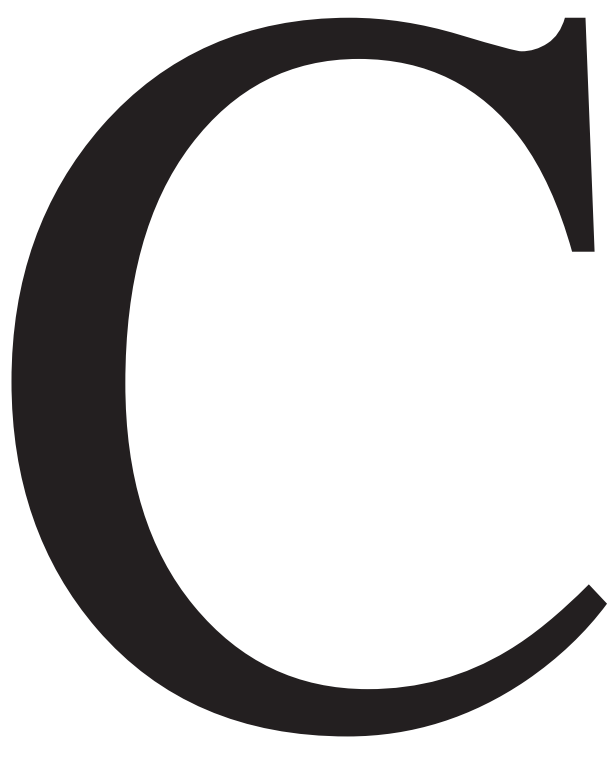

omemora-se neste ano o $180^{\circ}$ aniversário do anúncio da descoberta da daguerreotipia, o primeiro sistema fotográfico prático a ser colocado em uso. Mais além da importância do fato científico em si, tratou-se da descoberta de um meio de comunicação e expressão que alargaria os horizontes do homem para o conhecimento de si mesmo e do mundo que o cerca, para informá-lo sobre o presente e o passado, para alimentar seus sonhos e fantasias. Uma descoberta que teria papel cultural decisivo nos rumos da

BORIS KOSSOY é fotógrafo, pesquisador, professor titular da Escola de Comunicações e Artes da USP e autor de, entre outros, Fotografia e história (Ateliê Editorial). 
vida contemporânea. Impossível imaginar o mundo sem a fotografia.

$\mathrm{O}$ assunto é sedutor e se abre para inúmeros aspectos que poderiam ser abordados. O fenômeno da expansão da daguerreotipia e as formas de sua absorção social em diferentes latitudes são alguns desses aspectos que devem ser aprofundados. Isso nos leva ao objetivo específico do texto que se segue, que é o de revisitar o contexto e os fatos que marcam a introdução da daguerreotipia no Brasil.

Ao longo das pesquisas que tenho realizado sobre o tema venho observando que determinados fatos que tiveram lugar naqueles primeiros tempos merecem uma revisão crítica. É necessário reavaliar aspectos ainda controvertidos que cercam a obtenção dos mais antigos daguerreótipos produzidos no país.

É de conhecimento dos pesquisadores da fotografia no Brasil que, dentre os primeiros artefatos produzidos no princípio da década de 1840, apenas três sobreviveram (ou, pelo menos, os únicos que foram encontrados) ${ }^{1}$. As três imagens se referem a aspectos do Largo do Paço, do Rio de Janeiro, registrados pelo sistema da daguerreotipia. A identificação precisa de detalhes de natureza técnica relativos à sua produção, assim como dúvidas relativas à datação e autoria, ainda persistem. Tais aspectos, por vezes debatidos, não se viram, até o momento, convincentemente esclarecidos, como se constata pela historiografia. Um certo "mistério" ainda ronda a história dos primeiros daguerreótipos realizados no Brasil.

1 Esses artefatos integram a coleção do Arquivo Grão Pará, Petrópolis.

\section{A CHEGADA DO DAGUERREÓTIPO AO BRASIL}

A introdução da daguerreotipia no Brasil $^{2}$ se deu com a chegada da fragata L'Oriental (Wood, 1995, pp. 51-7), poucos meses após o celebrado 19 de agosto de 1839, data em que foi anunciada a descoberta de Daguerre ${ }^{3}$. O L'Oriental, sob o comando do capitão Augustin Lucas ${ }^{4}$, partiu de Nantes, na França, entre fins de setembro e início de outubro de 1839, atracando primeiramente em Lisboa e a seguir na Ilha da Madeira (Wood, 1995). A embarcação ainda fez escalas em Tenerife e Dakar, de onde seguiu rumo ao Brasil.

Pelo Jornal do Commercio é possível acompanhar o trajeto da embarcação em suas escalas por Recife, Salvador e Rio de Janeiro, onde aportou em 24 de dezembro de $1839^{5}$. A bordo viajava o protagonista de

2 Segundo Rupert Derek Wood, o L'Oriental era um navio-escola em viagem de circum-navegação, sob o patrocínio da França e da Bélgica. A embarcação transportava estudantes franceses, e da Bélgica seguiu viagem.

3 Louis Jacques Mandé Daguerre (1787-1851), pintor e cenógrafo, introdutor do diorama, um espetáculo cênico que obteve enorme sucesso em Paris. Foi associado à Nièpce que, em 1826, já havia descoberto um processo fotográfico. Em 1833, Nièpce veio a falecer e Daguerre seguiu com suas experiências, que resultaram na descoberta do daguerreótipo.

4 Augustin Lucas (1804-1854?) nasceu em Belle-lle, ilha situada na costa ocidental francesa da Bretanha. Desde cedo esteve ligado à marinha e ao comércio. No final da década de 1830 frequentava a Société d'Encouragement pour l'Industrie Nationale, conseguindo convencer seus membros a apoiarem uma expedição naval que pretendia realizar ao redor do mundo. Não fica claro o encontro do capitão Lucas com o abade Compte. Uma série de eventos não claramente esclarecidos cerca a vida de Lucas e seus familiares. Deve-se a ele a introdução do daguerreótipo em Sidney, Austrália, entre abril e maio de 1841. Dados extraídos de Wood (1995).

5 Jornal do Commercio, 25-26/dez./1839, p. 3. 
um fato histórico singular: o abade Louis Compte $^{6}$, a quem se deve as primeiras demonstrações da descoberta de Daguerre no Brasil e na América Latina?.

No dia 16 de janeiro de $1840^{8}$ (Turazzi, p. 22), uma quinta-feira, Compte apresentou aos brasileiros da Corte as primeiras demonstrações da daguerreotipia. O Jornal do Commercio de 17 de janeiro assim registrou o acontecimento:

"Finalmente passou o daguerreotypo para cá os mares, e a photographia, que até agora só era conhecida no Rio de Janeiro por theoria, he-o actualmente também pelos factos que excedem quanto se tem lido pelos jornaes tanto quanto vai do vivo ao pintado. Hoje de manhã teve lugar na hospedaria Pharoux ${ }^{9}$ hum ensaio photographico tanto mais interessante, quanto $\mathrm{He}$ a primeira vez que a nova maravilha se apresen-

6 Ou Comte (1798-1868), grafia que tem se alternado na historiografia. Louis Compte declara que teria tomado as primeiras lições do daguerreótipo com o próprio Daguerre.

7 Sobre o fato é interessante mencionar que, em evento organizado em comemoração ao centenário da fotografia em Lisboa, em 1939, teve lugar um ciclo de conferências organizado por Augusto da Silva Carvalho abrangendo temas de história e aplicações da fotografia em Portugal. Na comunicação de Carvalho tem-se, possivelmente, a primeira referência acerca da presença do daguerreótipo no Rio de Janeiro, o que não deixa de ser sugestivo em termos historiográficos (Carvalho, 1939, p. 24).

8 Turazzi esclarece convincentemente que o fato se deu no dia 16 e que a notícia foi publicada no dia seguinte. $O$ equívoco vem sendo reproduzido pela historiografia, como afirma a pesquisadora.

9 Louis Dominique Pharoux (?-1867), proprietário do hotel, era francês de Marselha, que chegou ao Brasil em 1815 ou 1816. O hotel se situava na Rua Fresca num prédio de três andares, além do térreo, que fazia frente para o Largo do Paço, tendo uma das fachadas voltadas para o mar (Praia Dom Manuel). ta aos olhos Brasileiros. Foi o abbade Combes [sic] quem fez a experiência: He hum dos viajantes que se acha a bordo da corveta franceza L'Orientale, o qual trouxe consigo o engenhoso instrumento de Daguerre, por causa da facilidade, com que por meio delle se obtem a representação dos objectos de que se deseja conservar a imagem. He preciso ter visto a cousa com os seus próprios olhos para se poder fazer idea da rapidez e do resultado da operação. Em menos de nove minutos o chafariz do Largo do Paço, a Praça do Peixe, o Mosteiro de S. Bento e todos os outros objectos circumstantes se acharão reproduzidos com tal fidelidade, precisão e minuciosidade, que bem se via que a cousa tinha sido feita pela propria mão da natureza, e quase sem intervenção do artista. Inutil eh encarecer a importância da descoberta de que já por vezes temos occupado os leitores; a exposição do facto diz mais do que todos os encarecimentos" $"$.

Poucos dias depois das experiências do Largo do Paço, é ainda o mesmo jornal que nos informa da visita empreendida pelo capitão Augustin Lucas e pelo abade Compte ao jovem imperador, na Quinta da Boa Vista, em São Cristóvão, residência da família imperial. Segundo o periódico, Compte teria, nessa oportunidade, demonstrado a técnica e o processo a D. Pedro II e às princesas Januária e Francisca, e tomado vistas do palácio e arredores.

Nos últimos dias de janeiro, o L'Oriental zarpava com destino a Montevidéu dando sequência à sua viagem pela América do

10 Jornal do Commercio, 17/jan./1840, p. 1. 


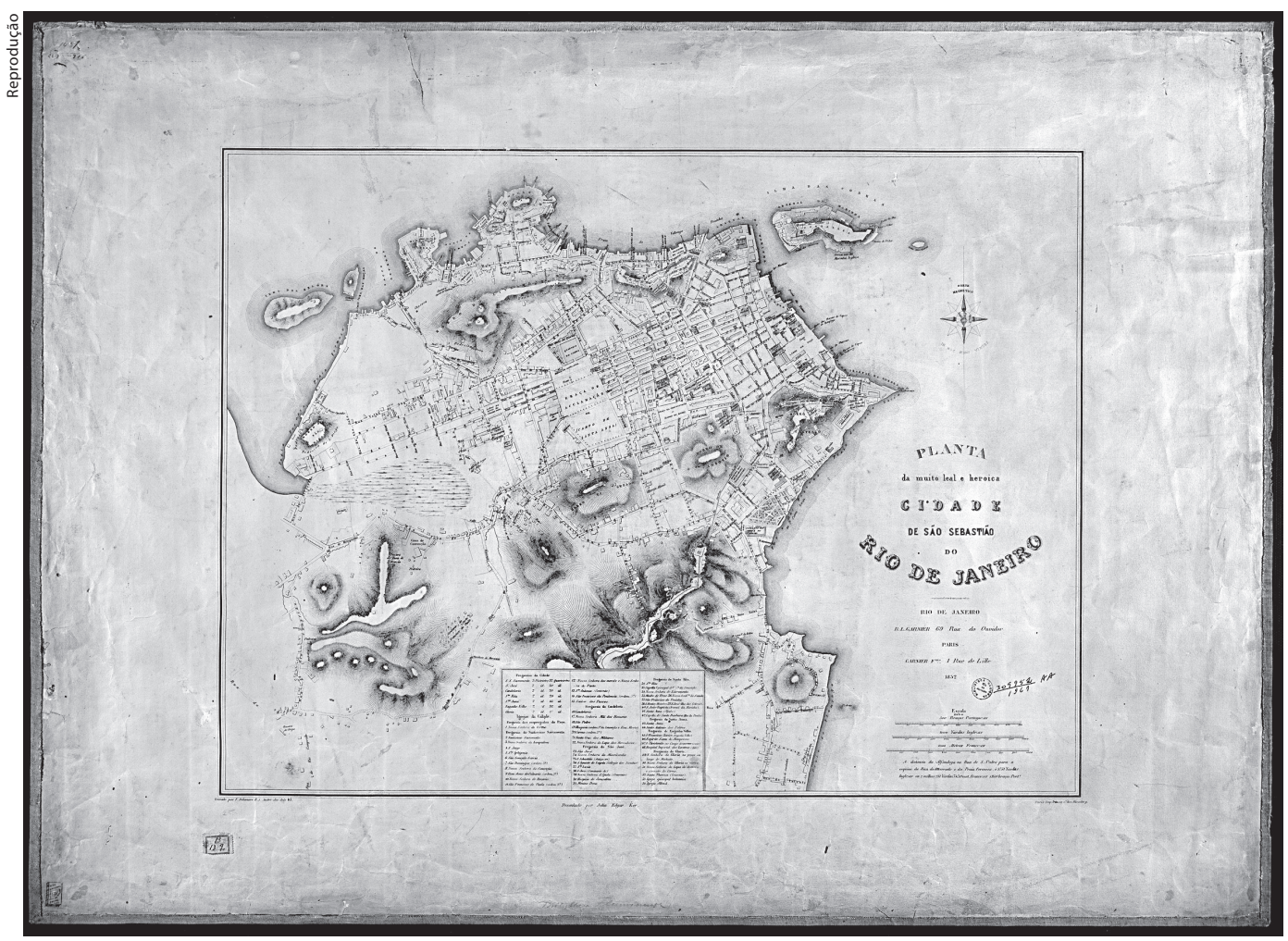

Planta da muito leal e heroica cidade de São Sebastião do Rio de Janeiro, 1852

Acervo da Biblioteca Nacional, Rio de Janeiro [cart. 309952]. Disponível em: http://objdigital.bn.br/ objdigital2/acervo_digital/div_cartografia/cart309952/cart309952.jpg.

Sul $^{11}$. Depois de Montevidéu o navio se dirigiu a Valparaiso, no Chile. Partindo daquele porto o L'Oriental naufragou, a 23 de junho de 1840, não se registrando vítimas.

\section{ANÁLISE DOS DAGUERREÓTIPOS DO CHAFARIZ E DO MERCADO DO PEIXE}

O texto do Jornal do Commercio de 17 de janeiro merece uma análise cuidadosa pelas pistas que oferece ao historiador. Pelo modo como o jornalista comenta a "rapidez [...] do

$11 \mathrm{O}$ abade, depois de apresentar a descoberta aos uruguaios da capital, em fevereiro de 1840, decidiu abandonar a expedição e se instalou na cidade, onde permaneceu por vários anos. resultado da operação" e a fidelidade com que "o chafariz do Largo do Paço, a Praça do Peixe, o Mosteiro de S. Bento [...] se acharão reproduzidos [...], em menos de nove minutos", o leitor comum não poderia ter sequer uma ideia aproximada da forma e do método pelo qual essa "reprodução" dos logradouros se materializou. A começar pela inconsistente menção que faz em relação ao "aparelho" de tomar vistas, utilizado pelo abade Compte ${ }^{12}$ (que, no mínimo, deve ter chamado a atenção dos populares que transitavam diante do

12 A câmera de Compte poderia ser do tipo "Giroux", introduzida em 1839. Tal parece plausível, na medida em que esse era o modelo "oficial" de câmera comercializado no momento em que o abade embarcou na sua viagem. No entanto, detalhes de ordem técnica quanto ao formato das chapas estão em desacordo. 
Hotel Pharoux), há um vácuo de informações importantes no relato do jornal.

Após a exposição na câmara, a imagem ainda latente se tornava visível mediante a ação do agente revelador ${ }^{13}$ e, permanente, depois de a placa ser mergulhada no banho fixador $^{14}$. Seguia-se a lavagem em água e secagem e por fim a montagem da chapa em sofisticada caixinha revestida internamente de veludo. Isso significa que a chapa sensível, além da longa exposição à luz ${ }^{15}$, ain-

13 A chapa era adaptada num ângulo de $45^{\circ}$ no interior de uma caixa vertical de madeira, de modo a receber o vapor de mercúrio aquecido, procedimento necessário para o surgimento gradativo da imagem, que poderia ser verificada no momento em que se formava. Assim era "revelada" a chapa.

14 Trata-se da imersão, por alguns minutos, da chapa já revelada no banho de hipossulfito de sódio, para que a imagem fosse fixada. Compte não submeteu a chapa ao banho de cloreto de ouro posteriormente à fixagem. Esse procedimento, descoberto pelo francês Hyppolite Fizeau (1819-1896), promovia maior contraste aos tons, protegia a superfície da abrasão e preservava a prata contra a oxidação; só entraria em uso após agosto de 1840.

15 O tempo de exposição necessário para a captura da imagem pelo sistema da daguerreotipia, quando este ainda se achava nos seus inícios (janeiro de 1840), varia de autor para autor. Além disso, as tabelas pesquisadas nas fontes referem-se, em geral, a informações que resultam da experiência europeia e norte-americana. De qualquer modo, existem fatores constantes a serem considerados que influenciam diretamente o tempo de exposição, seja no hemisfério norte ou no sul: a estação do ano, a hora do dia, as cores do objeto, o formato da chapa e da câmera, o tipo e qualidade da lente, a sensibilidade à luz da placa, entre outros. Josef Maria Eder fala entre 10 e 12 minutos para as tomadas realizadas durante o inverno, em dias nublados; no verão, em pleno sol, o tempo de exposição seria reduzido pela metade, isto é, entre cinco e seis minutos. Já nas regiões ao sul (da Europa) a exposição cairia ainda mais, para dois ou três minutos. Diante disso, a duração do tempo de exposição informada pelo jornalista do Jornal do Commercio ("menos de nove minutos") parece um tanto longa, possivelmente uma informação imprecisa: nunca saberemos quantos segundos (ou minutos) seriam exatamente "menos de nove...". O fato é que não se trata do relato de um especialista preocupado em detalhar com precisão o dado. Serve, portanto, a informação do jornalista mais como um indicativo. da necessitava de mais 30-40 minutos, ao menos, para poder ser apreciada. É curioso que o jornalista nada informe de específico sobre essa etapa dos procedimentos químicos conduzidos pelo capelão. No entanto, ao mencionar que "hoje de manhã teve lugar na hospedaria Pharoux hum ensaio photographico [...]", temos a confirmação de que foi justamente no Hotel Pharoux que Compte se achava hospedado. Em um dos aposentos que ocupava teria montado um laboratório improvisado, um quarto escuro com condições adequadas para efetuar os procedimentos químicos necessários.

Pelas imagens obtidas, entende-se que foi exatamente da fachada do prédio voltada para o largo que o capelão tomou suas vistas, no período da manhã, segundo informa o jornal. Contudo, a imagem do chafariz, especialmente, apresenta uma acentuada luminosidade da esquerda para a direita (como se observa pelo brilho nas arestas da esquerda, de alto a baixo, e nos degraus do monumento) que mais condiz com o sol da tarde a oeste, e numa posição ainda alta, poderia ser no início da tarde.

O leitor do artigo deve ter imaginado que apenas um daguerreótipo foi realizado. Reforça isso o fato de o articulista descrever o suposto conteúdo da imagem e o tempo de exposição para registrá-la. A impressão que se tem é que ele se refere apenas a uma única imagem:

"Em menos de nove minutos o chafariz do Largo do Paço, a Praça do Peixe, o Mosteiro de S. Bento e todos os outros objectos circumstantes se acharão reproduzidos com tal fidelidade [...]"16.

16 Jornal do Commercio, 17/jan./1840, p. 1. 


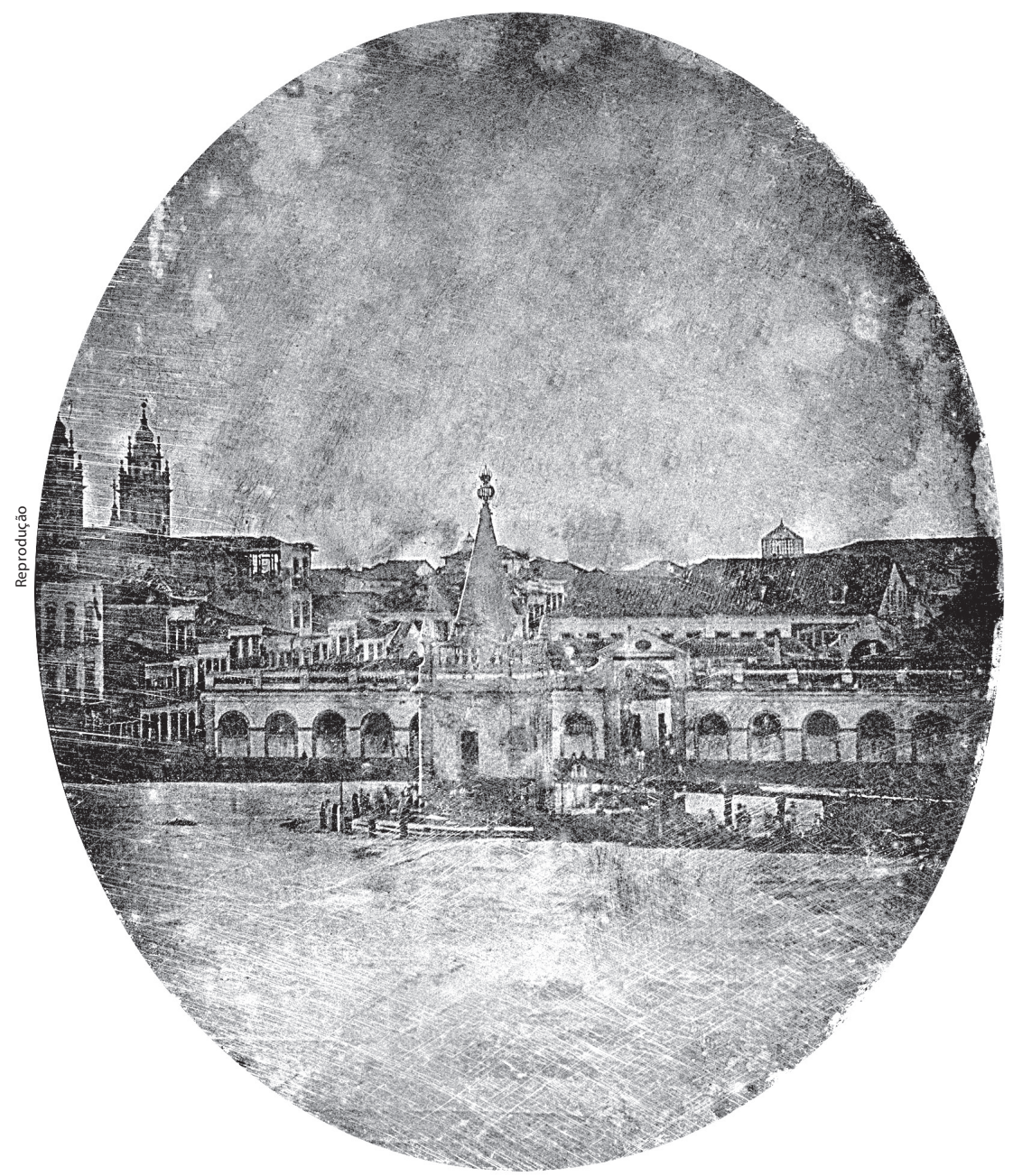

L. Compte, Chafariz do Largo do Paço, Rio de Janeiro, 16/1/1840,

daguerreótipo, 9 [8,3] × 7 cm [1/6 placa]. Arquivo Grão Pará, Petrópolis, RJ

Uma vista contendo esses três elementos (chafariz, Mercado do Peixe, Mosteiro de São Bento), tal como foi descrita, não corresponde ao objeto das vistas obtidas por Compte. Acredito que os dois daguerreótipos foram realizados em sequência: assim, numa das vistas temos o "chafariz do Largo do Paço" como objeto central da imagem e, na outra, "a Praça do Peixe" e o "Mosteiro de S. Bento", elevando-se ao fundo.

Ambos os daguerreótipos foram tomados no rumo noroeste, de um ponto de vista elevado, possivelmente do terceiro andar do
Hotel Pharoux. No primeiro deles vê-se, ao centro, o chafariz, obra do século XVIII de autoria de mestre Valentim ${ }^{17}$ (Faria, 2007), diante do Mercado do Peixe, cuja constru-

17 Valentim da Fonseca e Silva (c.1745-1813), escultor, entaIhador e arquiteto mineiro, era filho de um português, tratador de diamantes, e de uma escrava negra. Seu talento em pouco tempo lhe trouxe fama e passou a ser requisitado para projetar uma série de obras públicas, como o Passeio Público, além de esculturas e chafarizes como o da Pirâmide, ou Chafariz de Mestre Valentim, obra realizada por volta de 1779-1780. Foi edificado à beira-mar e abastecia de água os moradores, assim como as embarcações que aportavam em frente. 
ção foi iniciada nos meados da década de 1830 e finalizada entre 1841 e 1842 , obra do arquiteto francês Grandjean de Montigny ${ }^{18}$. $\mathrm{Na}$ extremidade esquerda veem-se as torres da Igreja de N. S. da Candelária, uma delas completamente e, a outra, apenas em parte, tangenciando a curvatura do passe-partout de formato oval que recobre a imagem do daguerreótipo. Junto ao chafariz existia uma rústica calha de madeira que levava a água para as embarcações. A condição da imagem nesse ponto é das piores, mas ainda assim nota-se o que parece ser a forma dessa calha que se prolonga à direita, em ligeiro declive. Atrás do chafariz, no centro da fachada do mercado, eleva-se um arco acima da edificação, encimado por um frontão neoclássico. Pode-se perceber pela imagem (e planta) que arcos idênticos foram construídos no centro das quatro fachadas (Largo do Paço, Praia do Peixe, Rua do Ouvidor e Rua do Mercado). Por trás do mercado vê-se o prédio da Alfândega e, ao fundo e acima, um trecho do Morro de São Bento, numa tonalidade muito escura que poderia se confundir com os telhados à frente.

A vista contida no segundo daguerreótipo realizado por Compte foi tomada igualmente no rumo noroeste, porém com a câmera voltada ligeiramente para a direita em relação à descrita antes e, certamente, do mesmo ponto de vista. Esse registro, como também já referido, foi tomado provavelmente

18 Auguste Henri Victor Grandjean de Montigny (17761850), formado pela École d'Architecture de Paris, integrou a Missão Artística Francesa que veio para o Brasil em 1816. Foi professor de arquitetura da Academia Imperial de Belas Artes, onde inaugurou o ensino formal de arquitetura no país, e é considerado como um dos principais responsáveis pela afirmação do neoclassicismo como arquitetura oficial. na mesma ocasião (16 de janeiro de 1840). A imagem documenta, da esquerda para a direita, o canto da edificação que abrigava o mercado, Praia do Peixe e embarcações; ao centro, possivelmente, o trapiche Maxwell e parte do prédio da Alfândega e, ao fundo, o Mosteiro de São Bento, localizado no morro de mesmo nome e, no sopé desse morro, o Arsenal da Marinha (que mal se distingue), que, aos poucos, vai se expandindo para a Ilha das Cobras, à direita. Diante do mercado descobre-se parte da calha que transportava a água do chafariz avançando em direção ao mar, com sua estrutura visível ao centro e na parte inferior da imagem.

Observei detidamente as duas imagens na tentativa de identificar a presença ou não de pessoas. A questão que se coloca de pronto é a da possibilidade de registrar temas não estáticos como pessoas caminhando ou transportando cargas, realizando algum trabalho braçal, carroças ou carruagens em movimento, entre outros tipos de atividade que poderiam ocorrer naquele local e época. Levando em conta o longo tempo de exposição necessário para se obter um registro perfeito, isso seria possível? Acreditamos que não, para o caso de o objeto do registro se achar em movimento constante e rápido. $\mathrm{O}$ resultado seria uma mancha ou um total vazio na imagem. No entanto, se uma pessoa estivesse parada num mesmo lugar durante todo o tempo da exposição, o registro poderia ser possível, apesar da óbvia perda de nitidez, em função de breves movimentos involuntários. Exemplo clássico disso é o afamado daguerreótipo de autoria do próprio Daguerre, na primavera de 1838 , tomado de sua janela, onde se vê um homem tendo suas botas engraxadas no Boulevard du Temple, em Paris. Embora se- 
jam personagens minúsculos no contexto da paisagem, eles são identificáveis justamente por terem se mantido no mesmo lugar por cerca de 10 minutos, apesar dos pequenos porém inevitáveis movimentos. Não se vê mais ninguém na via pública, isto em função, possivelmente, do movimento rápido de eventuais pedestres e veículos. Interessante ainda observar que um letreiro promocional afixado em uma das edificações ao fundo daquele boulevard foi registrado com o texto ao contrário. E isso se explica porque as imagens do daguerreótipo se apresentam lateralmente invertidas. Naquele momento ainda não havia sido desenvolvido o acessório para inverter a orientação da imagem para a posição correta.
De volta ao exame dos nossos daguerreótipos, é de se ressaltar o mau estado de conservação em que se apresentam esses artefatos; de outra parte, o exame das reproduções e ampliações dos artefatos também não permite que se façam afirmações definitivas. Apesar disso, tem-se a vaga impressão que existem, sim, pessoas, especialmente no daguerreótipo que registra o chafariz do Mestre Valentim. Reforça isso a iconografia histórica do Largo do Paço tal como foi representada pelas obras de Debret, Buvelot e Moreaux, Pustkow, d'Hastrel, entre outros, que nos mostram a ininterrupta presença de escravos ao redor do chafariz em busca de água, sem falarmos nos pedestres, em várias situações, que transitavam pelo local.

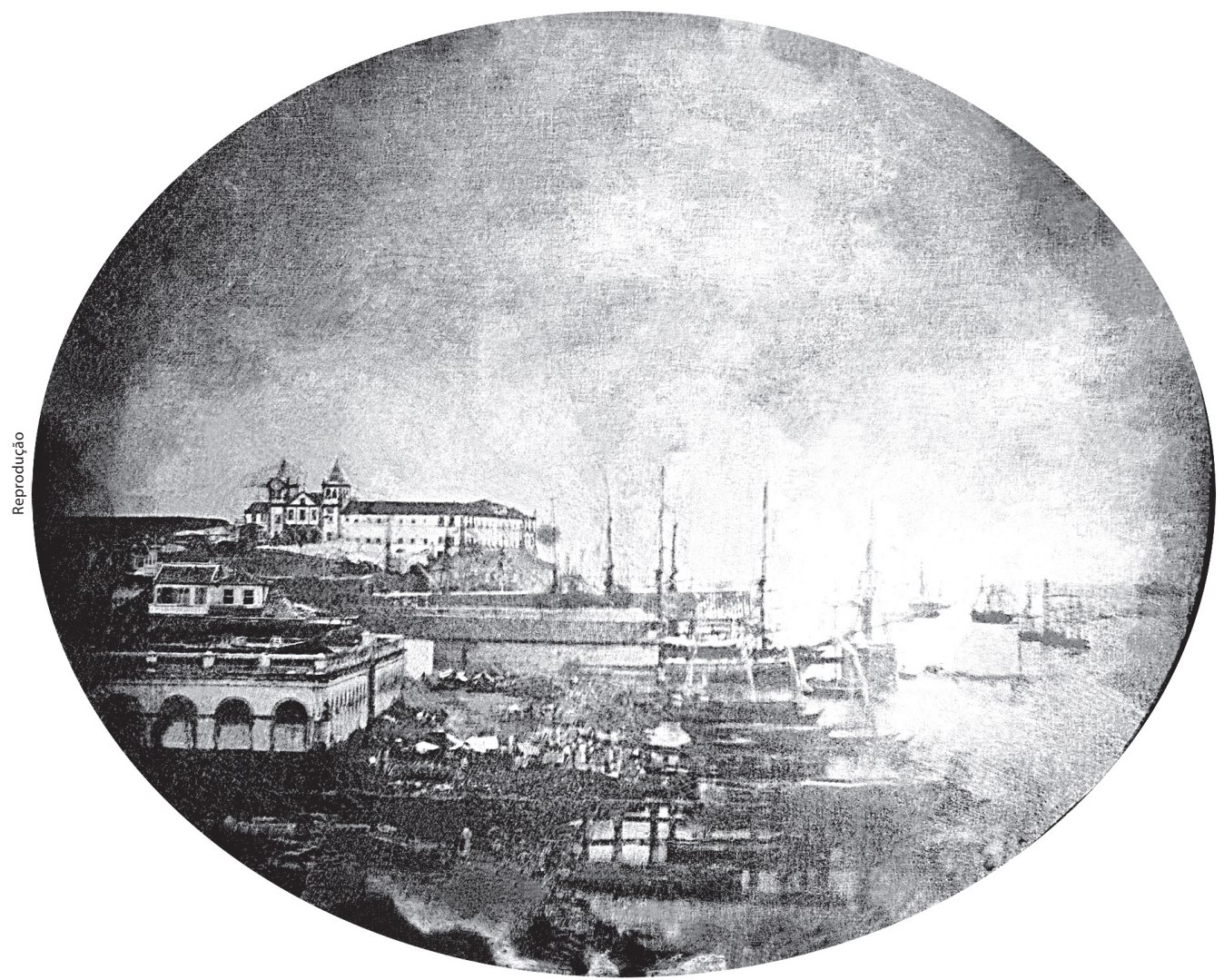

L. Compte, Vista parcial do Mercado da Praia do Peixe, Rio de Janeiro, 16/1/1840, daguerreótipo, 7 × 9 [8,3] cm [1/6 placa]. Arquivo Grão Pará, Petrópolis, RJ 


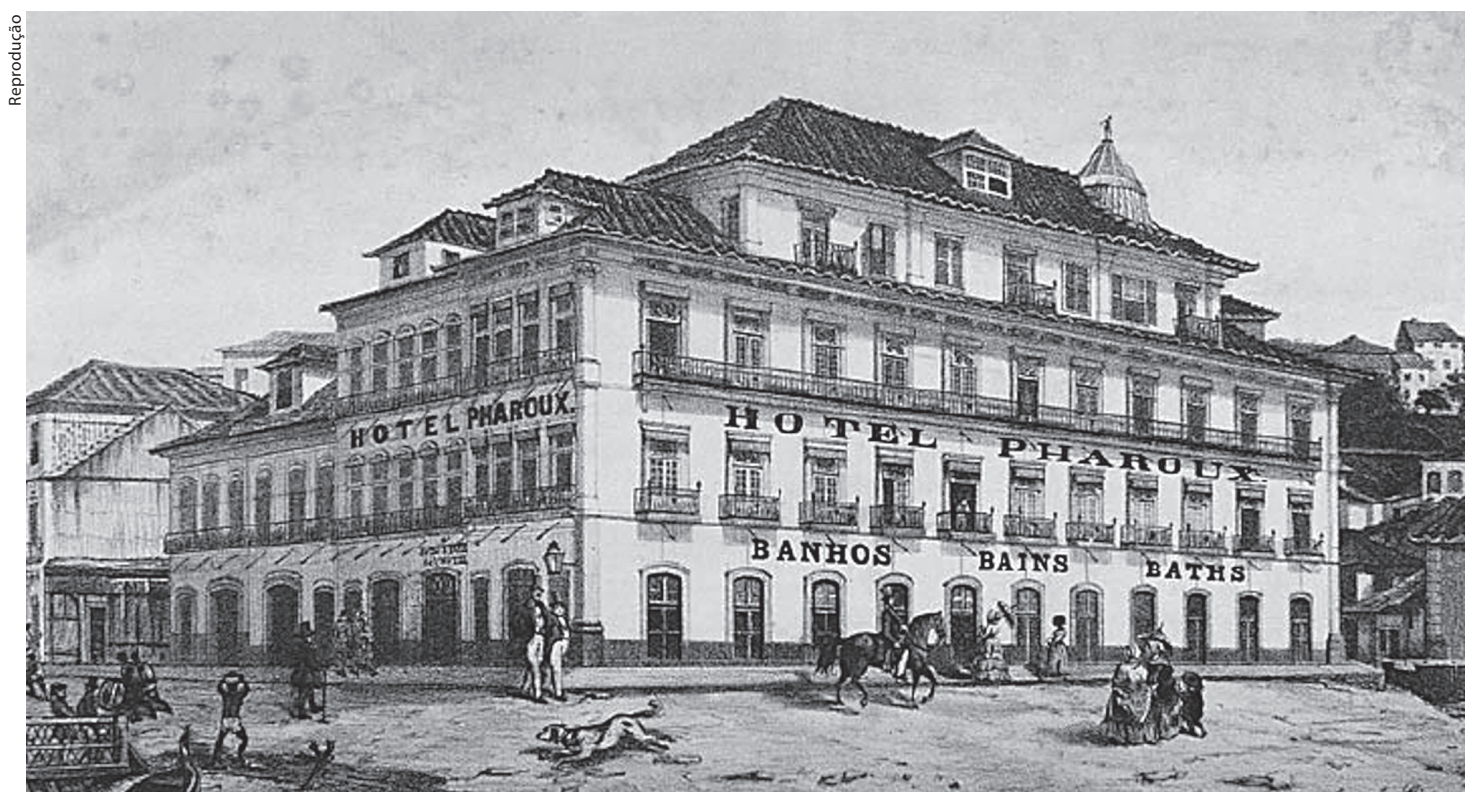

Sébastien Auguste Sisson, Hotel Pharoux (lados NW e NE), Rio de Janeiro,

1850-1862, litografia aquartelada, 28,5 × 36,2 cm. Cortesia Instituto Sébastien Sisson

Entretanto, como disse acima, não poderia confirmar neste momento o registro de pessoas no daguerreótipo sem ter certeza absoluta. Para tanto, recomendo que observações e reproduções dos artefatos originais sejam realizadas por meio de tecnologia especializada.

Desde há muito já havia percebido que uma faixa horizontal escura (Morro de São Bento) por sobre o prédio da Alfândega, à direita e ao alto do daguerreótipo do chafariz, tem continuidade no lado esquerdo do daguerreótipo do Mercado do Peixe, e o mesmo ocorre com relação ao próprio prédio do mercado, mais abaixo. Com a junção dos dois daguerreótipos, nota-se que o morro e os detalhes construtivos da fachada do mercado se completam, coincidindo perfeitamente.

As duas vistas foram registradas, certamente, do mesmo balcão ou janela, provavelmente no terceiro andar do prédio do Hotel Pharoux, a partir de um mesmo ponto de vista, apenas com um pequeno giro horizontal da câmera para um lado ou para o outro. A altura do solo até o ponto de vista foi calculada de forma aproximada pela comparação com a cota do chafariz (cerca de $14 \mathrm{~m})^{19}$. Da mesma forma, as distâncias do ponto de vista dos dois objetos foram determinadas pela escala de distâncias constante do mapa que foi utilizado para esta pesquisa ${ }^{20}$. Assim, do ponto de vista no Hotel Pharoux até o prédio do mercado tem-se uma distância aproximada de 185 metros e, do mesmo ponto, até o chafariz, 147 metros, tam-

19 Apesar de ter consultado extensa bibliografia sobre os monumentos históricos do Rio de Janeiro, não consegui encontrar nenhuma referência sobre a altura exata do chafariz do Mestre Valentim.

20 Planta da muito leal e honrosa cidade de São Sebastião do Rio de Janeiro, de 1852. 


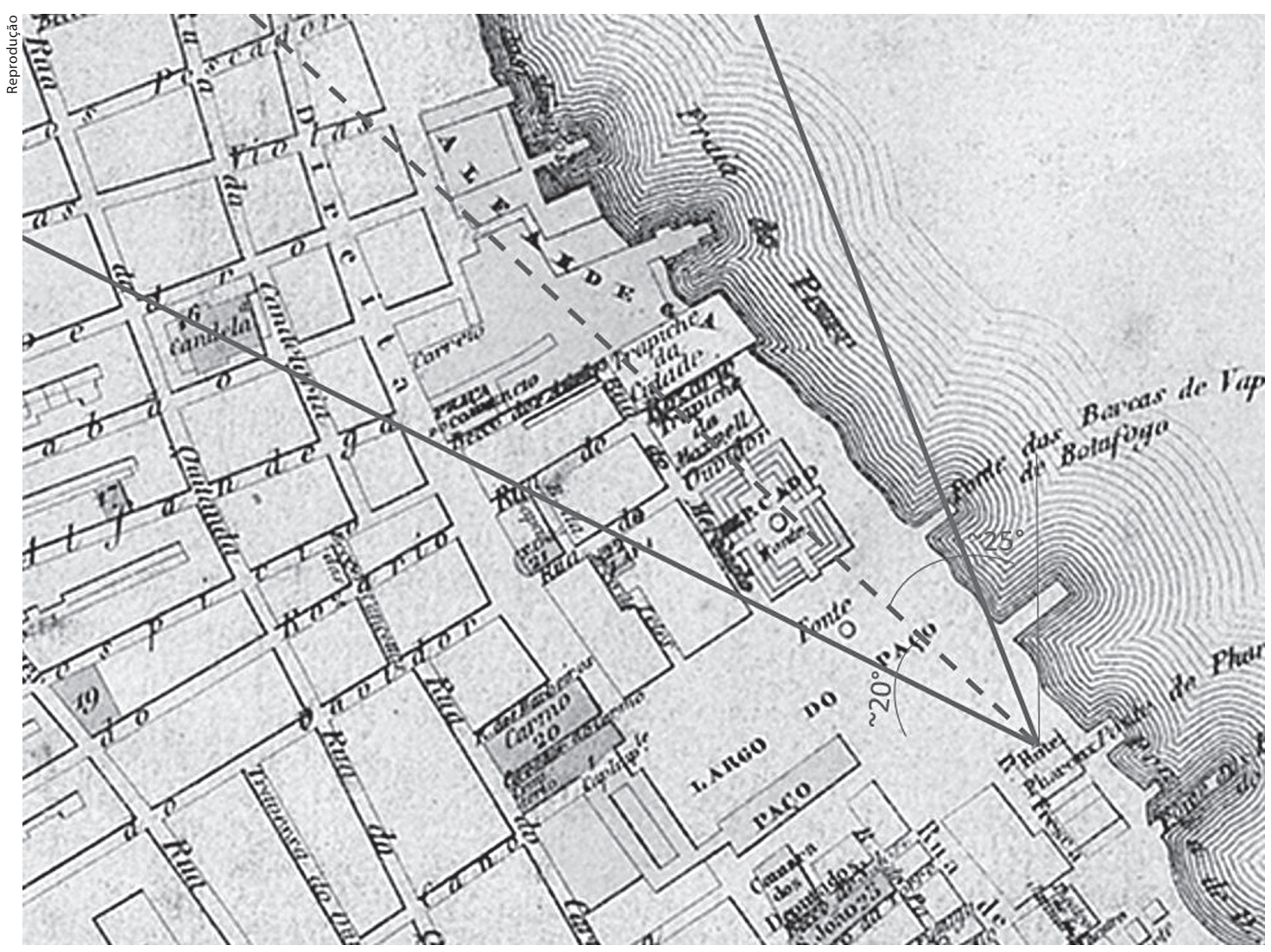

Ponto de vista e ângulos das tomadas das vistas do chafariz do Mestre Valentim e do Mercado do Peixe

bém de forma aproximativa ${ }^{21}$. Pelo ponto de vista determinado e pelo campo visual que cada vista abrange traçamos as linhas que formam os dois ângulos de visada: a do mercado, $25^{\circ}$, e a do chafariz, $20^{\circ}$ aproximadamente ${ }^{22}$.

É de se louvar a ideia do daguerreotipista de realizar duas vistas em sequência, tomadas do mesmo ponto de vista. Teria ele imaginado que um panorama poderia ser formado pela junção das duas imagens? A sobreposição das vistas permite que tenha-

21 Idem.

220 traçado e a determinação dos ângulos são de André Luís de Lima. mos um panorama fotográfico ainda inédito daquele trecho do conjunto urbano do centro da cidade, em $1840^{23}$.

Após o famoso 19 de agosto de 1839, em que a descoberta de Daguerre foi anunciada, pesquisadores de diferentes países passaram a desenvolver aperfeiçoamentos ópticos, como já foi mencionado anteriormente, além de um novo desenho para a câmera, incluindo a diminuição do seu formato assim como das chapas. A inversão dos lados é natural nas imagens do daguerreótipo. Para "corrigir" o problema recomendou-

23 A fusão dos dois daguerreótipos é de autoria do fotógrafo Zé de Boni. 


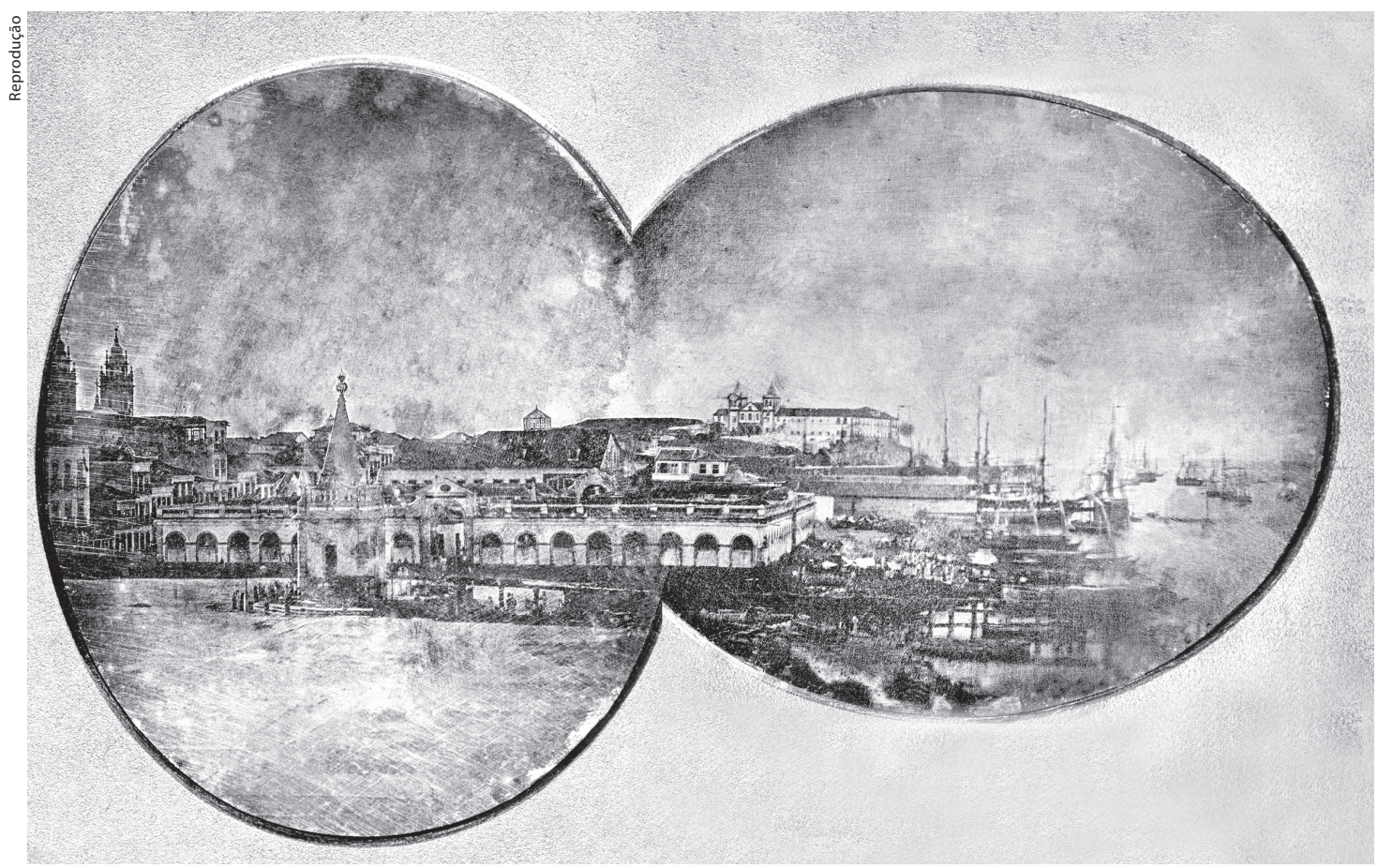

Panorama formado pela fusão das vistas dos daguerreótipos do chafariz

do Largo do Paço (esquerda) e do Mercado do Peixe (direita). Montagem: Zé de Boni

-se o uso de um espelho ou prisma que era colocado diante da lente de forma a inverter novamente a imagem e, portanto, trazer o tema para a posição normal. O próprio Daguerre já havia percebido isso e indicado um acessório no seu Manual de procedimentos, verdadeira bíblia dos usuários e aprendizes, publicado em múltiplas edições e idiomas (Daguerre et al., 1839). Esse artifício foi muito oportuno para as vistas de natureza, arquitetura e o traçado urbano das cidades, entre outros temas. É possível que Compte tivesse empregado o dispositivo em suas vistas. Se não é esse o caso as imagens se apresentariam invertidas e uma operação de refotografar o original com outro daguerreótipo seria necessária, a fim de repor os lados na posição correta. Se tal ocorreu, quem teria feito as reproduções? E quando?
Algumas questões ainda não se acham suficientemente esclarecidas em relação à atuação de Compte. Entre elas mencionamos a dificuldade de se reconstituir tecnicamente a produção dos daguerreótipos sem termos informações precisas sobre o equipamento por ele usado (modelo da câmera, lentes), inclusive para confirmar o formato da chapa de $1 / 6$ " ou 7 × $8,3 \mathrm{~cm}$, que não era usual naqueles primeiros meses que se seguiram à descoberta. Nenhuma possibilidade deve ser descartada, até mesmo a de os artefatos terem sido reproduzidos, quem sabe dois anos depois, pelo daguerreotipista A. Morand, que prestou serviços ao Imperador inclusive reproduzindo retratos ("copying portraits"). Esta é, ainda, mera suposição.

De qualquer modo, fato comprovado pelo testemunho da imprensa (Jornal do Commercio) é que Compte é o autor de vistas 
tomadas em janeiro de 1840, porém algum mistério ainda ronda os próprios daguerreótipos do Largo do Paço.

\section{A VISITA DO PRÍNCIPE}

\section{ADALBERTO DA PRÚSSIA}

Nos primeiros dias de setembro de 1842 , o príncipe Adalberto da Prússia ${ }^{24}$ aportou no Rio de Janeiro, com o intuito de permanecer alguns meses na capital do Império, antes de seguir viagem para a Amazônia. No dia 8 daquele mês anotou em seu diário:

“[...] Sua Majestade teve [...] a grande bondade de dar-me dois daguerreótipos de São Cristóvão, feitos por um artista estrangeiro de quem já me tinha falado. $\mathrm{O}$ imperador mesmo já tinha feito diversas experiências com a daguerreotipia, e era de opinião que o acaso provavelmente desempenharia nela o principal papel".

Não há dúvida de que os daguerreótipos que o príncipe Adalberto recebeu de presente do imperador sejam os mesmos realizados no Palácio da Boa Vista (São Cristóvão), dois anos antes, pelo abade Compte, por ocasião da visita que fez ao imperador, noticiada por um periódico local ${ }^{25}$. Seria ele, pois, o "artista estrangeiro" mencionado por Adalberto em seu diário. Nada se sabe sobre o paradeiro desses artefatos fotográficos.

24 O príncipe Adalberto da Prússia, Henrique Guilherme Adalberto (1811-1873), era irmão do rei Frederico GuiIherme III e primo de D. Pedro II. Foi militar do Exército Prussiano, realizou viagens por diversos países e esteve no Brasil em 1842.

25 Jornal do Commercio, 20-21/jan./1840, p. 4.

\section{IMPRECISÕES HISTORIOGRÁFICAS}

Quando se fala das vistas fotográficas mais antigas do Rio de Janeiro, é de se notar que o daguerreótipo que representa o Paço da Cidade, com a guarda imperial perfilada à frente, tem sido geralmente incluído com os dois anteriores como se fosse parte de um mesmo conjunto. Isso faria supor que a vista em questão seria de 1840 , e fora tomada na mesma ocasião que as anteriores, logo, só poderia ser de autoria do capelão Louis Compte ${ }^{26}$. Outros sugerem a possibilidade desse artefato ter sido produzido em 1842 por Morand e Smith. Ainda há os que acreditam ter sido o mesmo tomado anos depois, já na década de 1850 .

Algumas evidências, entretanto, nos levam a crer que esse daguerreótipo foi tomado durante a permanência de Morand e Smith no Rio de Janeiro, como veremos a seguir.

\section{A RÁPIDA TRAJETÓRIA DE MORAND E SMITH NO BRASIL}

Em 1842, dois pioneiros daguerreotipistas desembarcavam no Brasil, provenientes de Nova York ${ }^{27}$. Era ele Augustus Morand Jr. (1815-1862?) acompanhado de um sócio ou ajudante, James E. Smith. Permaneceram no Rio de Janeiro entre o final de 1842 e o mês de abril de 1843, exercendo a atividade

26 Foi essa a primeira interpretação quanto à datação e autoria desse daguerreótipo, linha que foi encabeçada por Gilberto Ferrez, ainda em 1946, em sua obra. Essas informações tornaram-se referências consolidadas e levaram pesquisadores nas décadas seguintes a reproduzirem o mesmo equívoco. Sobre este assunto voltaremos adiante.

27 Jornal do Commercio, 26/nov./1842, p. 4. 
de retratistas pelo daguerreótipo. Nas vésperas do Natal, os daguerreotipistas assim se anunciavam:

"Morand e Smith, artistas do daguerreotypo, tem a honra de informar ao respeitavel publico desta corte que estabelecerão o seu gabinete no hotel Pharoux salão 52, casa nova, $2^{\circ}$ andar, onde trabalharão todos os dias das 8 horas da manhã ás 3 da tarde. Os annunciantes, tendo a convicção de poder satisfazer completamente as pessoas que se dignarem honra-los, convidão os amadores das artes, e todo os que desejarem ter um retrato perfeito, um quadro de família ou vista qualquer, a visitar o seu gabinete" ${ }^{28}$.

Vê-se, pelo anúncio, que o retrato era o objetivo principal do empreendimento. Com o "gabinete" adaptado no "salão 52" do Hotel Pharoux, aliás o primeiro estabelecimento comercial dessa modalidade a ser instalado na cidade, inaugurava-se no Brasil a tradição do retrato fotográfico de estúdio, que atravessaria o século XIX e grande parte do XX.

$\mathrm{O}$ retrato pelo daguerreótipo, no momento em que o abade Compte passou pelo Brasil, ainda era tarefa impossível de ser realizada. Dois anos depois, quando Morand e Smith se achavam no Rio de Janeiro, os registros já não demandavam longas exposições. Pelo contrário, entre 1840 e 1842, importantes aperfeiçoamentos técnicos haviam sido introduzidos: lentes mais luminosas e "aceleradores" químicos foram desenvolvidos; as chapas se tornaram muito mais

28 Jornal do Commercio, 24/dez./1842, p. 2. O mesmo anúncio continuou a ser publicado nos últimos dias do ano e foi repetido em cerca de 25 edições do jornal entre janeiro e fevereiro de 1843. sensíveis e, portanto, o tempo de exposição diminuiu drasticamente ${ }^{29}$. O daguerreótipo do Largo do Paço de Morand e Smith, obtido mediante equipamentos e materiais produzidos de acordo com as mais recentes técnicas, requereu certamente um tempo de exposição de apenas alguns segundos.

Tudo indica que o mestre da dupla Morand e Smith era o primeiro. É dele que se tem notícia como um daguerreotipista renomado cujo estúdio se tornou muito conhecido mais tarde em Nova York, onde se fixou. Não obstante, eram ambos sempre referidos nas matérias da imprensa do Rio de Janeiro.

"Os habeis artistas no daguerreotypo, os Srs. Smith e Morand, de quem já tivemos occasião de fallar, merecerão a honra de ser chamados ao paço para tirarem os retratos de S.M.I. e das augustas princezas, e algumas vistas da quinta da Boa-Vista"30.

Em março de 1843, Morand comentou com o jornalista do Jornal do Commercio a sua intenção de encerrar as suas atividades na capital do Império, "dentro de três semanas". O jornal noticiou o fato e acrescentou uma informação do maior interesse:

29 As chapas passaram a ser sensibilizadas por meio do uso combinado de sais de prata mais efetivos como o bromo, iodo e cloro. As antigas lentes projetadas por Desiré Chevalier foram substituídas por outras de maior diâmetro e luminosidade, desenhadas pelo matemático e óptico húngaro Joseph Max Petzval (1807-1891). Além disso, o tempo de exposição era maior ou menor de acordo com o tamanho da câmera e a distância focal das lentes. Chapas com formatos menores requeriam menos tempo. Sabemos que o formato da chapa utilizada por Morand era de $23 / 4 x$ $31 / 4$ (polegadas) ou $7,0 \mathrm{~cm} \times 8,3 \mathrm{~cm}$.

30 Jornal do Commercio, 27/jan./1843, p. 3. 
"Os Srs. Morand e Smith, artistas do daguerreotypo, de quem ja por vezes tivemos a occasião de fallar, mostrarão nos uma serie de vistas do largo do Paço e outros lugares da vizinhança, tiradas por elles no ponto maior que admitte esta qualidade de trabalho, e com summa perfeição"31.

É provável que Morand tenha se decidido a retornar aos Estados Unidos por motivo de saúde. Em 13 de abril embarcava para Nova York. Em 1848 inaugurou sua "galeria" nessa cidade e em 1851 tornou-se presidente da N.Y. State Daguerreian Association (Newhall, 1975, p. 149).

\section{ANÁLISE DO DAGUERREÓTIPO DO LARGO DO PAÇO}

Poderia ser de autoria de Morand e Smith o daguerreótipo do Largo do Paço? Existem pistas na imagem que podem levar à determinação correta dos elementos constituintes e das coordenadas de situação do artefato? São muitas as variáveis e questões que se apresentam, para tanto seguimos a seguinte metodologia de análise iconográfica:

- Estudo comparativo da iconografia pictórica e fotográfica referente à arquitetura das edificações civis, religiosas e institucionais e do espaço urbano; e também dos demais elementos icônicos registrados nas imagens existentes sobre o Paço da cidade visando a determinar sua datação; estudo da implantação das platibandas na fachada

31 Jornal do Commercio, 9/mar./1843, p. 3. do palácio; determinação aproximada do ponto de vista, ângulos e distâncias aos objetos registrados.

- A contextualização do que se vê na imagem remete à história da vida urbana do Rio de Janeiro nos meados do século XIX, assim como à da atividade fotográfica no momento em que a daguerreotipia se instalava no país. A pesquisa de hemeroteca supriu este trabalho com informações valiosas, como, por exemplo, a sequência dos hotéis que se estabeleceram no Largo do Paço, bem como as atividades comerciais e administrativas que lá ocorriam naqueles anos. Por fim, foi de extrema utilidade a análise do relato do reverendo Daniel Parish Kidder ${ }^{32}$, obtido diretamente de Augustus Morand e publicado em revista especializada em fotografia nos Estados Unidos, uma fonte de época confiável (Kidder, 1851). Da mesma forma, os livros publicados pelo reverendo sobre sua permanência no Brasil trouxeram informações precisas para este estudo (Kidder, 1940; Fletcher \& Kidder, 1879).

Uma das dificuldades de datação desse daguerreótipo diz respeito à construção das platibandas do Paço Imperial, daí a importância da iconografia pictórica. Em 1840, ano em que o abade tomou suas vistas, o palácio não contava com platibandas. Numa

32 Missionário da Igreja Metodista Americana, Daniel Parish Kidder (1815-1891) esteve no Brasil entre 1837 e 1840 , período em que realizou viagens pelas províncias do Sul e do Norte. Deixou dois livros sobre o Brasil, Reminiscências de viagens e permanência no Brasil, publicado em 1845 nos EUA, e Brasil e os brasileiros (Brazil and the Brazilians, portrayed in historical and descriptive sketches), em coautoria com James Cooley Fletcher. 


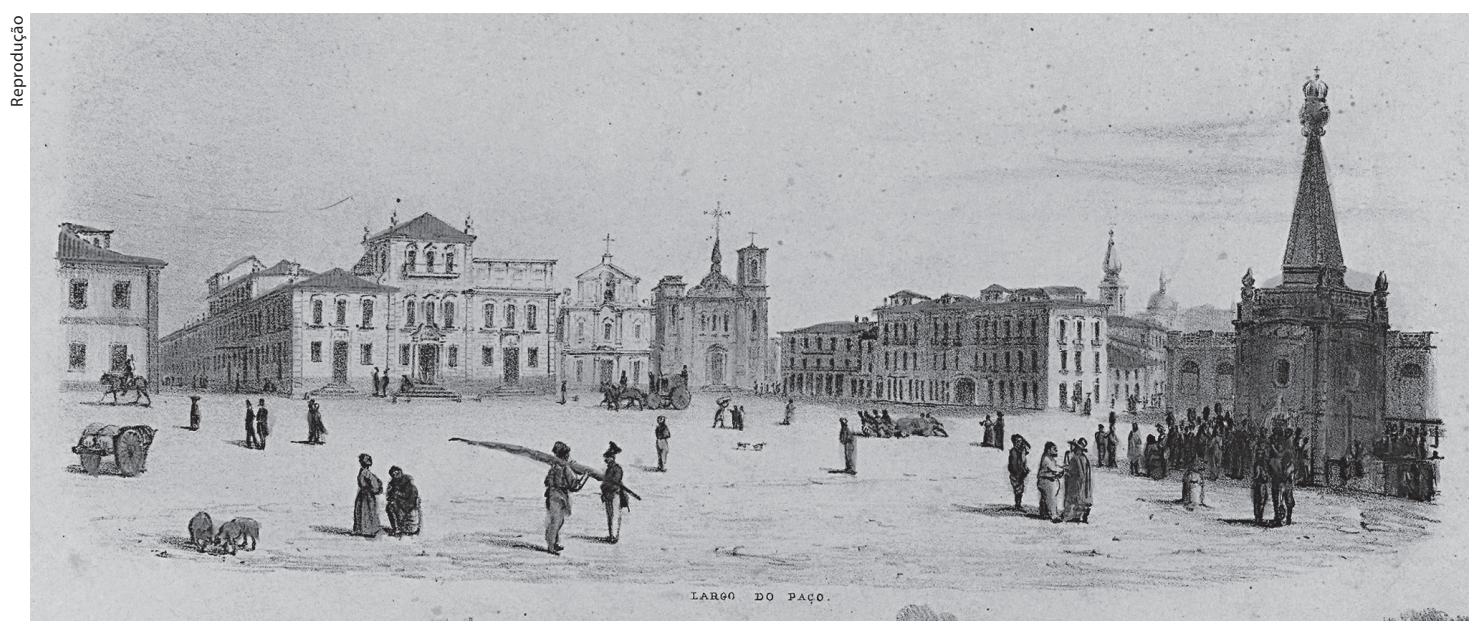

A. L. Buvelot e A. Moreaux, Largo do Paço (detalhe), Rio de Janeiro pittoresco, gravura, Heaton e Rensburg, 1845 [gravura impressa em 1842]. Casa Geyer/Museu Imperial//bram/Minc, 2019

litogravura de Buvelot ${ }^{33}$ e Moreaux, realizada no ano de 1841 (Coroação e sagração de D. Pedro II), podemos ver que no corpo da fachada do prédio, que forma o canto com a fachada lateral do lado direito, já havia sido erigida platibanda de inspiração neoclássica.

Naquele ano, foram realizadas reformas no palácio em razão dos preparativos para a coroação do imperador, fato que se deu no mês de julho. Entre 1841 e princípios de 1842 os mesmos artistas, trabalhando num conjunto de vistas da cidade, documentaram novamente o Largo do Paço, desta vez num dia comum, uma cena cotidiana. O palácio é representado, mais uma vez, apenas com uma platibanda do lado direito ${ }^{34}$.

33 Abraham Louis Buvelot (1814-1888), suiço de nascimento, chegou ao Brasil em 1835. Foi pintor, desenhista, gravador e um dos primeiros daguerreotipistas do Rio de Janeiro. Em companhia de Louis Auguste Moreaux desenhou vistas e costumes urbanos. Em 1845, fundou estabelecimento de daguerreotipia na Rua dos Latoeiros, 36, permanecendo em atividade até 1856. Em 1860, retornou ao seu país natal e, posteriormente, se fixou em Melbourne, Austrália.

34 Jornal do Commercio, 24/mar./1842, p. 3. Esta gravura fazia parte da primeira série de estampas litográficas
Aqui estabelece-se um enigma: quando Morand e Smith chegaram ao Rio de Janeiro, a mencionada platibanda do lado esquerdo já havia sido construída? A construção poderia ter ocorrido no período em que se encontravam no Brasil? Ou, então, foi construída depois de terem deixado o país? E, sendo este o caso, quem teria sido o autor?

Desde logo, devemos considerar que vários profissionais se estabeleceram na cidade a partir de 1842. É o caso, por exemplo, de Mme. Hypolite Lavenue, pioneira mulher retratista no Brasil ${ }^{35}$, e J. Elliot ${ }^{36}$ (Kossoy, 2002, p. 126), que se anunciavam conco-

que foram postas à venda nos estabelecimentos de Georges Leuzinger e de Laemmert. Mais tarde, seriam reunidas com outras para formarem o álbum completo do Rio de Janeiro pittoresco, obra que foi lançada em 1845 por Heaton \& Rensburg.

35 Jornal do Commercio, 28/dez./1842, p. 4. Mme. Lavenue informava suas atividades de retratista sucessivas vezes entre finais de dezembro de 1842 e princípios de 1843.

$36 \mathrm{~J}$. Elliot teria chegado ao Brasil em 1842; em março do ano seguinte se anunciava à Rua Direita, 14. 
mitantemente à Morand nos periódicos locais. Outros daguerreotipistas estrangeiros começam a chegar logo após o retorno de Morand aos Estados Unidos, como J. Davis $^{37}$ (Kossoy, 2002, p. 118), Geanne, Gerbig, Hoffmann e Keller, Chauvin, todos de rápida passagem pela cidade. Devemos lembrar igualmente aqueles que já se achavam no Brasil, como é o caso de Bautz $^{38}$ e de Buvelot, pintores estabelecidos na capital do Império, que nos meados da década começaram a se dedicar também à daguerreotipia. Outros daguerreotipistas, mais para o final da década de 1840 , como Telfer $^{39}$ (Kossoy, 2002, p. 306) e Williams ${ }^{40}$ (Kossoy, 2002, p. 328) também poderiam estar entre os hipotéticos autores da vista.

Nesta altura faremos uma breve apreciação sobre os trabalhos de alguns pesquisadores que se debruçaram sobre a matéria, de forma a situar as diferentes linhas interpretativas.

A partir de Gilberto Ferrez, autor de uma sistematização pioneira sobre a fotografia no Brasil, tem-se a informação de que o artefato em pauta seria também de autoria do abade Compte. Esta afirmação é encontrada em sua obra A fotografia no Brasil

37 J. Davis, por exemplo, foi sucessor de Morand e Smith, estabelecendo-se igualmente no Hotel Pharoux. Informa que adquiriu de Morand "uma grande porção de laminas" (Jornal do Commercio, 25/abr./1843, p. 4).

380 alemão Francisco Napoleão Bautz abriu sua "officina para tirar retratos" na Rua do Cano, 146, em maio de 1846 (cf. Jornal do Commercio, 5/abr./1846, p. 3).

39 Guilherme Telfer esteve em atividade entre 1849 e 1855; inicialmente estabelecido à Rua do Hospício, 63, transferiu-se depois para a Rua do Ouvidor, 126, e Rua dos Ourives, 34.

40 W. R. Williams, possivelmente norte-americano, inaugurou seu estabelecimento à Rua do Ouvidor, 56, em maio de 1848, permanecendo em atividade até 1851. e um de seus mais fiéis servidores: Marc Ferrez (Ferrez, 1946, p. 6) e reafirmada na reedição ampliada da obra (Ferrez, 1985, pp. 17 e ss.). Nesta última, Ferrez comenta em nota haver uma "controvérsia" sobre a autoria do terceiro daguerreótipo, exatamente o que representa o Paço Imperial (Ferrez, 1985, p. 231).

Esclarece que, em outro livro, publicado anos antes em coautoria com Weston Naef (Ferrez \& Naef, 1976), este último discordava de se considerar Compte como o autor do mencionado daguerreótipo, atribuindo tal feito ao norte-americano Augustus Morand. A identificação da respectiva imagem reproduzida no livro (Attributed to Augustus Morand) segue essa orientação, predominando aparentemente a opinião de Naef ${ }^{41}$ (Ferrez \& Naef, 1976, pp. 15-6). $\mathrm{Na}$ mesma obra, entretanto, os autores se mostram contraditórios afirmando ser improvável que o daguerreótipo seja de 1842 , pois, segundo eles, a possibilidade técnica de interrupção do movimento (refere-se aos personagens da cena) só seria possível após aquela data ${ }^{42}$. Em 1842, as chapas muito mais sensíveis já permitiam exposições de alguns segundos, especialmente nas cenas externas e luminosas como é o caso do tema em questão, tomada em pleno verão do Rio de Janeiro.

O fato é que a determinação da data e autoria do daguerreótipo proposta por Ferrez

41 Apesar dessa discordância, e como já foi mencionado antes, Gilberto Ferrez, na versão de 1985 de seu livro, continua atribuindo o daguerreótipo a Louis Compte: "[...] primeiro daguerreótipo tirado na América do Sul, em janeiro de 1840".

42 "It is very unlikely that a daguerreotype made in 1842 could recorded such a transient event", nas palavras dos autores. 
prevaleceu por muitos anos e consolidou-se na historiografia. Eu mesmo, dentre outros pesquisadores, acabamos reproduzindo essas informações em nossas obras.

No artigo de Sylvie Pénichon (2004, pp. 317-31) sobre a daguerreotipia no Brasil, a autoria do daguerreótipo é atribuída a Morand. Sem embargo, é curioso que a pesquisadora se refira em nota à menção de Pedro Corrêa do Lago (2000, pp. 230-1) acerca da possibilidade de o alemão Napoleão Bautz ter sido o daguerreotipista (fato que teria ocorrido na década de 1850), porém não discorde nem questione a colocação do referido autor.

Lago faz um balanço sobre a datação e autoria do daguerreótipo segundo a interpretação de diferentes autores que aqui reproduzimos:

"Outra corrente sustenta que somente o Mercado da Candelária e o Chafariz do Mestre Valentim seriam de Compte, e que o daguerreótipo que representa o Paço da Cidade com a tropa formada à frente seria muito posterior [sic], pois só em 1851 teria sido aberto o Hotel de France, que aparece no fundo da imagem com seu nome legível [sic]. [...] Também a torre da Igreja do Carmo, também visível na fotografia, só teria ficado pronta em 1849. A conclusão desses pesquisadores (liderados por Ramon Poyares) é de que este daguerreótipo poderia ser de autoria de F. N. Bautz [sic] daguerreotipista estabelecido no Rio de Janeiro de 1847 a 1853" (Lago, 2000, p. 230).

Pedro Vasquez (2003, p. 30), de sua parte, reproduz a especulação de Lago e situa a complexidade da questão que, de fato, vem confundindo os pesquisadores há muito tempo.

Algumas incorreções devem ser reparadas. Primeira, o hotel que se vê ao fundo não é o Hotel de France. Segunda, as torres da Igreja da Venerável Ordem Terceira de N. S. do Carmo ainda não aparecem na imagem. O que se vê acima do telhado do palácio, à esquerda, é a cúpula da Igreja de N. S. do Carmo da antiga Sé e, ao centro, a sineira provisória da Igreja da Ordem Terceira do Carmo. As torres definitivas ${ }^{43}$, com suas cúpulas bulbosas, foram edificadas entre 1847 e 1850 , portanto, o daguerreótipo foi obtido antes dessas datas, caso contrário as torres estariam despontando ao fundo da imagem, já prontas ou ainda em obras. Sobre as datas da construção definitiva das torres esclarece Moreira de Azevedo (1877, pp. 219-22):

"Recomeçando em 1814 a obra das torres, ficou concluída a do lado da epístola até a abertura dos sinos; e sendo prior em 1845 João Baptista Lopes Gonçalves agenciou uma subscrição entre os irmãos da ordem, [...] offereceu um risco feito por Manoel Joaquim de Mello Côrte Real, e dando começo a obra em 16 de julho de 1847, vio concluida uma das torres em 14 de outubro de 1849 , e a outra em 14 de outubro de $1850[\ldots] "$.

Diante disso, a atribuição da autoria à Bautz é incorreta. Assim como a data.

43 Projeto de Manoel Joaquim de Mello Côrte Real, professor de desenho da Academia Imperial de Belas Artes. 


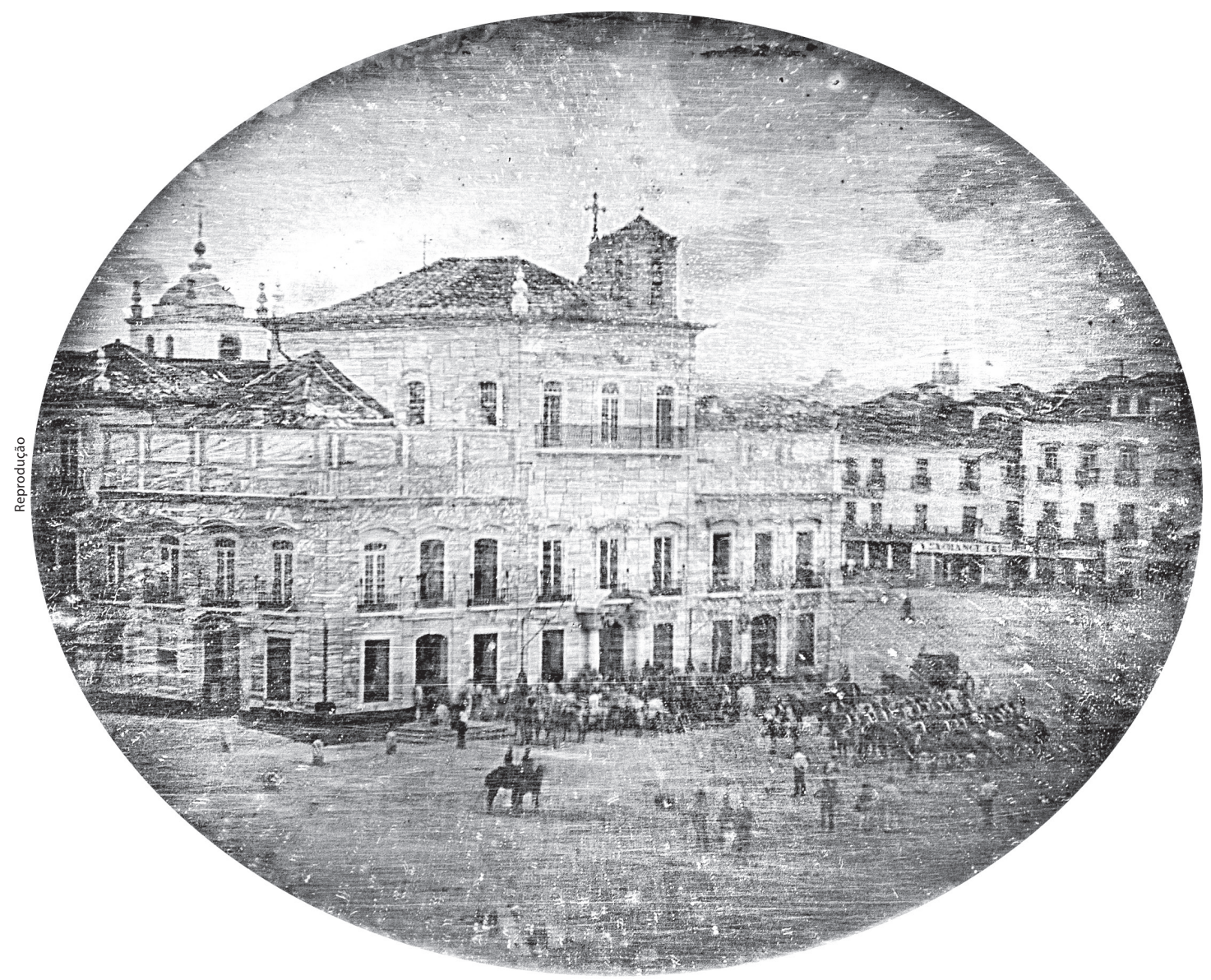

A. Morand e J. Smith, Paço da Cidade, Rio de Janeiro [entre dezembro de 1842 e abril de 1843], daguerreótipo, 7 × 9 [8,3] cm [1/6 placa]. Acervo Grão Pará, Petrópolis, RJ

Existem indícios consistentes de que a vista é de autoria de Morand e Smith, entre 1842-1843, e foi tomada possivelmente numa manhã de um dia nublado (pelo menos é o que parece, pela luz difusa da cena), no rumo noroeste-oeste. $\mathrm{O}$ registro se fez do Hotel Pharoux, possivelmente do local onde os daguerreotipistas mantinham seu "gabinete", no salão $52,2^{\circ}$ andar, do lado em que o prédio faz frente para a Rua Fresca (fachada lateral). O ângulo que abrange a imagem é de $25^{\circ}$ aproximadamente. Da janela do seu estabelecimento, Morand tinha uma visão excelente do palácio e do movimento de pedestres, comerciantes e escravos que transitavam no largo. A distância do Hotel Pharoux ao palácio era de aproximadamente 119 $\operatorname{metros}^{44}$.

A descrição que o reverendo norte-americano Daniel Parish Kidder faz da vista do Paço Imperial tomada por Morand é coerente, embora não seja um testemunho direto. Trata-se de um depoimento de segunda mão, pois quando da chegada de Morand ao Rio de Janeiro, o reverendo

440 traçado e a determinação do ângulo e ponto de vista são de André Luís de Lima. 


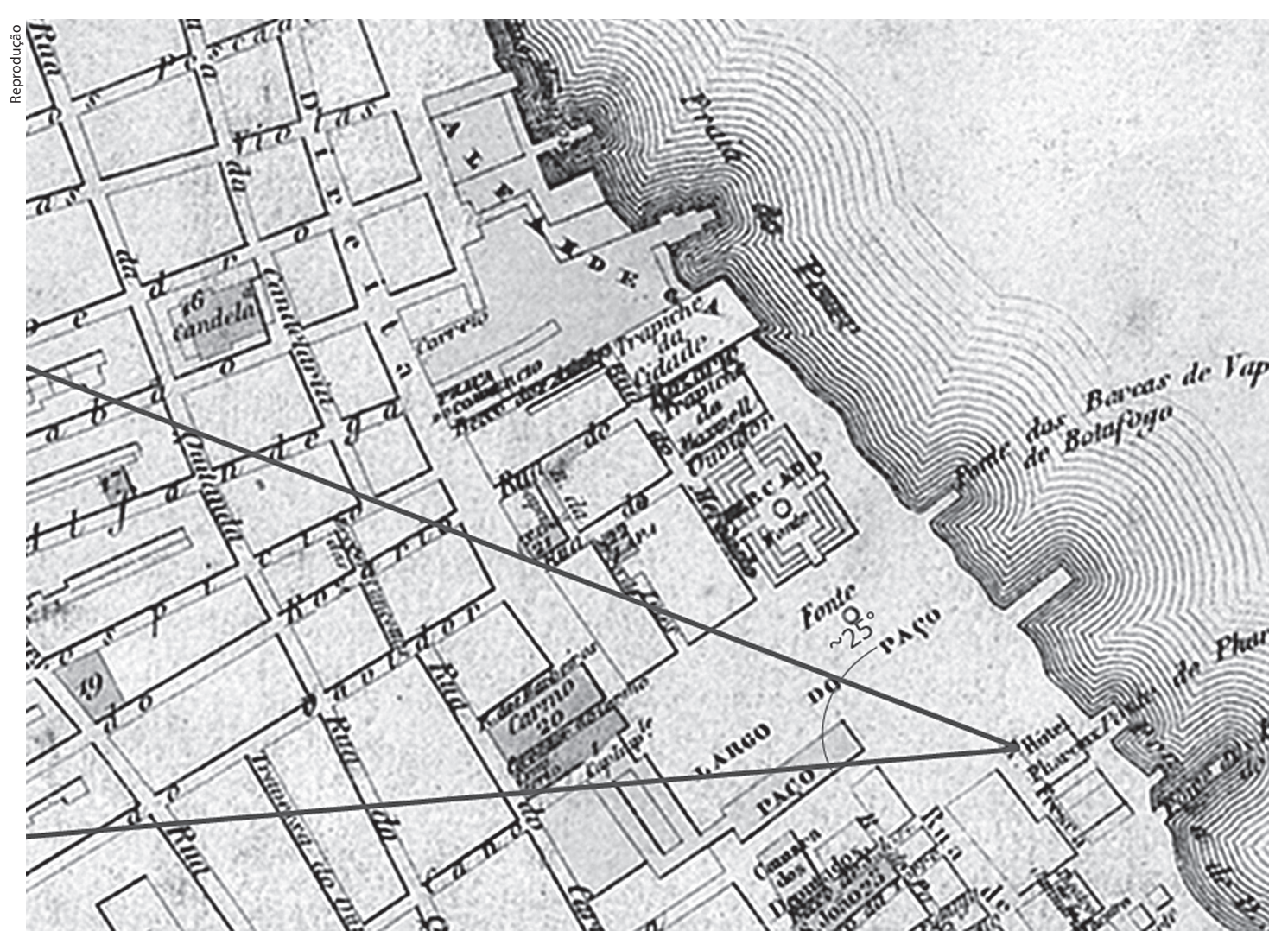

Ponto de vista e ângulos das tomadas da vista do Largo do Paço. Arquiteto André Luís de Lima

já havia retornado aos Estados Unidos. Kidder teve conhecimento sobre os detalhes da produção da imagem anos depois, informado que foi pelo próprio Morand, nos Estados Unidos. Não poupa elogios ao compatriota no que se refere às suas qualidades morais e profissionais no artigo que escreveu para uma publicação pioneira sobre a fotografia, nos Estados Unidos ${ }^{45}$ :

“[...] Ter conhecido o Sr. Morand pessoalmente legitima plenamente a expressão da mais profunda admiração por suas quali-

45 Tradução deste e dos demais trechos do artigo por Carol Colffield. dades de coração e mente e, inquestionavelmente, a pureza de propósito que ele trouxe à sua investigação e prática tem sido um elemento primordial do êxito em seu esforço para promover a arte da fotografia" (Kidder, 1851, pp. 237-9).

No mesmo artigo Kidder relata os vários trabalhos encomendados pelo imperador D. Pedro II, reconhecendo a qualidade artística de Morand, como mencionamos anteriormente:

“[...] Pelo período de quase cinco meses ele esteve quase que constantemente a serviço do imperador, fosse registrando vistas das belas paisagens nos arredores da Residência Imperial em 'São Cristóvão', a cerca de 6,5 
milhas da cidade, copiando retratos na Galeria Real de Pinturas, ou fazendo daguerreótipos de membros da Família Imperial [...]. Fez também vários retratos de Dona Francisca, irmã mais nova do imperador, que é agora a esposa do príncipe de Joinville, filho do falecido Louis Philippe, rei dos franceses".

No que se refere especificamente à realização da imagem do Paço Imperial, o reverendo relata:

"Um dos exemplos mais interessantes talvez já produzidos pela arte fotográfica foi realizado pelo Sr. Morand no Rio; era costume do imperador visitar todos os sábados de manhã seu palácio na cidade. Em uma dessas ocasiões, considerou que era uma excelente oportunidade para produzir uma bela imagem do imperador com sua guarda e seu esplêndido equipamento. Tendo preparado suas placas uma hora antes, aguardava a chegada deles.

No horário habitual, a guarda se aproximou um pouco à frente da carruagem do imperador; no instante em que parou e enquanto o imperador estava no ato de sair de sua carruagem, o sr. M. expôs sua placa e, em um segundo, obteve uma imagem verdadeiramente bela.

O corpo da guarda, composto por 40 cavaleiros, estava, com apenas uma ou duas exceções, perfeito, assim como o 'Major Domo' no ato de ajoelhar-se para beijar a mão do imperador enquanto saía da carruagem. A semelhança do próprio imperador era muito acurada.

O tempo total consumido em tirar, terminar e emoldurar a imagem foi de menos de 40 minutos desde o momento em que ele chegou ao palácio.
O imperador duvidou do fato, até que a sua atenção se voltou para a carruagem [representada] na chapa, quando assentiu imediatamente, pois era a que lhe havia sido presenteada pela rainha Vitória, e que não usava havia vários meses. $\mathrm{O}$ imperador estava em êxtase com a imagem e ordenou que ela fosse pendurada na Galeria Imperial, onde permanece; um testemunho ao empreendimento e habilidade de nosso artista americano. O studio do Sr. M. foi enriquecido por muitas vistas tiradas dos lugares mais bonitos do Rio de Janeiro e, não fosse por sua saúde debilitada, um panorama daguerreano completo teria sido o resultado de sua estada nos trópicos" ${ }^{\prime 4}$.

A descrição parece se referir a um evento que de fato ocorreu. O estado de conservação da chapa não é dos melhores. Em função disso não se tem uma imagem nítida da carruagem, nem da guarda e mesmo da platibanda da esquerda e do telhado ao fundo, que parecem estar em obras.

O livro Reminiscências de viagens $e$ permanência no Brasil de Daniel Parish Kidder contém ilustrações reproduzidas de gravuras sobre várias localidades, costumes e edificações do Rio de Janeiro e de São Paulo. Na página 55 da edição que consultamos (1940), vê-se uma vista tomada junto às edificações das igrejas, que forma o limite posterior do Largo do Paço, em direção à Rua Direita; deste ângulo o ilustrador desenhou as casas dos Telles, onde se pode ler a placa com os dizeres "Hotel de

46 Ver, também, Newhall (1975). Nessa obra, Newhall reproduz o texto publicado no Photographic Art Journal (Kidder, 1851). 
France" na parte térrea. O livro foi lançado nos Estados Unidos como Sketches of residence and travel in Brazil, em 1845 (data constante do Prefácio do próprio autor).

A apresentação da versão brasileira de Reminiscências é assinada por Rubens Borba de Morais, o qual esclarece que as ilustrações foram extraídas da obra Brazil and the Brazilians (Kidder, 1879), publicada nos Estados Unidos em 1857. Brasil e os brasileiros é a terceira obra de Kidder sobre o Brasil, publicada posteriormente em colaboração com o pastor James Cooley Fletcher, que também andou pelo Brasil entre 1851 e 1854. As duas obras se assemelham, mas a última teve grande sucesso merecendo uma dezena de edições sucessivas e tornando-se, segundo Borba de Morais, uma clássica referência sobre o Brasil para os americanos. Informa ainda que a obra foi "mais generosamente ilustrada, tanto que aproveitamos para esta edição das Reminiscências as gravuras mais interessantes de Brasil e os brasileiros".

Isso pode explicar a placa do "Hotel de France" identificando o local (que, pela documentação estudada, foi inaugurado em 1851) e as torres com cúpulas bulbosas da Igreja de N. S. da Ordem Terceira do Carmo já edificadas (construídas entre 1847 e 1850), na ilustração mencionada acima, aplicada à versão brasileira de Reminiscências.

$\mathrm{O}$ casario ao fundo e à direita que se observa na imagem também nos traz interessantes informações. Na esquina da Rua Direita (depois Primeiro de Março) com o Largo do Paço achavam-se construídas, desde o século XVIII, edificações de uso misto, moradias e comércio, de propriedade da família Telles de Menezes. Entre essas edificações existe uma passagem (Travessa do Comércio) que liga o Largo do Paço à Rua do Ouvidor; a ligação, no seu início junto ao largo, tem a forma de um arco abaulado, que se prolonga formando uma pequena cobertura. Tornou-se conhecido como "Arco do Telles", que sobrevive até hoje. À direita dessa passagem, continuam as edificações que faceiam o largo até encontrar a Rua do Mercado.

No início da década de 1840, o Hotel do Império $^{47}$ se achava instalado na edificação que faz esquina com a Rua Direita; de sua varanda, hóspedes e convidados assistiram aos festejos da coroação do jovem imperador Pedro II no dia 18 de julho de 1841. Em 1845 o antigo estabelecimento mudou de direção, passando a se chamar Hotel do Universo ${ }^{48}$, que permaneceu até 1850. Em agosto desse ano o estabelecimento foi adquirido pelo proprietário do antigo Hotel de Itália, o qual funcionou sob esse nome até abril de $1851^{49}$. Finalmente, em maio de 1851, aparece pela primeira vez o anúncio do Hotel de France ${ }^{50}$, sempre no mesmo local. No pavimento térreo do casario se sucediam várias lojas comerciais e os pavimentos superiores eram aparentemente divididos em salas e locados para escritórios, atividades essas que lá permaneceram durante décadas. Esses negócios podem ser recuperados pelos anúncios dos

47 Um anunciante de nome Neauville informava ao público que, após ampla reforma, reabria seu estabelecimento no Largo do Paço "com o novo título de Hotel do Imperio" (O Despertador, 13/ago./1840, p. 4).

48 A inauguração do estabelecimento se deu a 22 de maio, conforme anunciado no Jornal do Commercio (20/mai./1845, p. 4).

49 Jornal do Commercio, 3/abr./1851, p. 4.

50 Jornal do Commercio, 24/mai./1851, p. 4. 
jornais, quase sempre se referindo ao Largo do Paço, 14: venda de "tabaco, rapé [...] recentemente chegado de França" ${ }^{51}$; venda de "relógios americanos com corda para 8 dias"; lojas de câmbio ou escritórios que preparavam passaportes, "agenciam-se com brevidade" ${ }^{2}$.

Em termos de ocupação comercial, é de se notar que, entre a Praça do Comércio que abrigava a Alfândega e as edificações dos Telles, que principiavam na esquina da Rua Direita com o Largo do Paço, conta-se uma expressiva relação de cambistas, corretores e despachantes da Alfândega anunciando seus serviços regularmente. $\mathrm{O}$ missionário Kidder (1879, p. 28) refere-se precisamente ao local:

"A Praça do Commercio ou Bolsa ocupa uma posição proeminente na Rua Direita. Este edifício, anteriormente parte da Alfândega, foi cedido pelo Governo para os seus propósitos atuais em 1834. Ele contém uma sala de leitura, abastecida com jornais brasileiros e estrangeiros e está sujeita às regulamentações habituais de tais estabelecimentos em outras cidades... A Bolsa não fica longe da Alfândega, que antigamente tinha sua entrada principal adjacente à Praça".

A "Praça do Commercio" era identificada como local de reunião de homens de negócios, aparentemente, um "ponto" de encontro, onde funcionava a Bolsa de Valores. O prédio da primeira Praça do
Comércio foi projetado por Grandjean de Montigny e construído entre 1817 e 1820 . Comerciantes estrangeiros se referiam ao lugar como "Exchange" (ingleses ou norte-americanos) ou "Bourse" (franceses). Em 1842 um novo escritório se estabelecia: "New Agency Office, at the Exchange" e, no mesmo anúncio: "Nouveau bureau d'agence

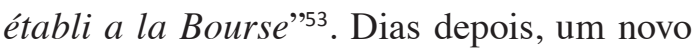
anúncio é publicado: "New Agency Office at the Exchange. Passports for passengers can be obtained at the shortest notice by calling at the 2nd. Office on entering the exchange" ${ }^{54}$.

Outros estabelecimentos que operavam com câmbio e/ou emissão de passaportes, que apareciam nos anúncios, como o do prédio da Rua Direita, esquina com o Largo, são constantes, variando a numeração de acordo com as datas, ao longo da década de 1840 .

A minuciosa descrição do daguerreótipo do Paço, cujos detalhes foram transmitidos por Morand a Kidder nos Estados Unidos, durante o encontro que tiveram em Nova York, dá consistência à suposição de ter sido de fato Morand o autor do referido artefato, em algum momento durante os meses em que permaneceu no Brasil (novembro de 1842 e abril de 1843). Disso deduz-se que a construção da platibanda do canto esquerdo foi realizada depois da segunda vista desenhada por Buvelot e Moreaux (no início do ano de 1842). Pode ter sido construída antes mesmo da chegada de Morand

53 Jornal do Commercio, 12/abr./1842, p. 4. O endereço completo era: "Praça do Commercio, $2^{\circ}$ escriptorio a direita".

54 Jornal do Commercio, 23/abr./1842, p. 4. 


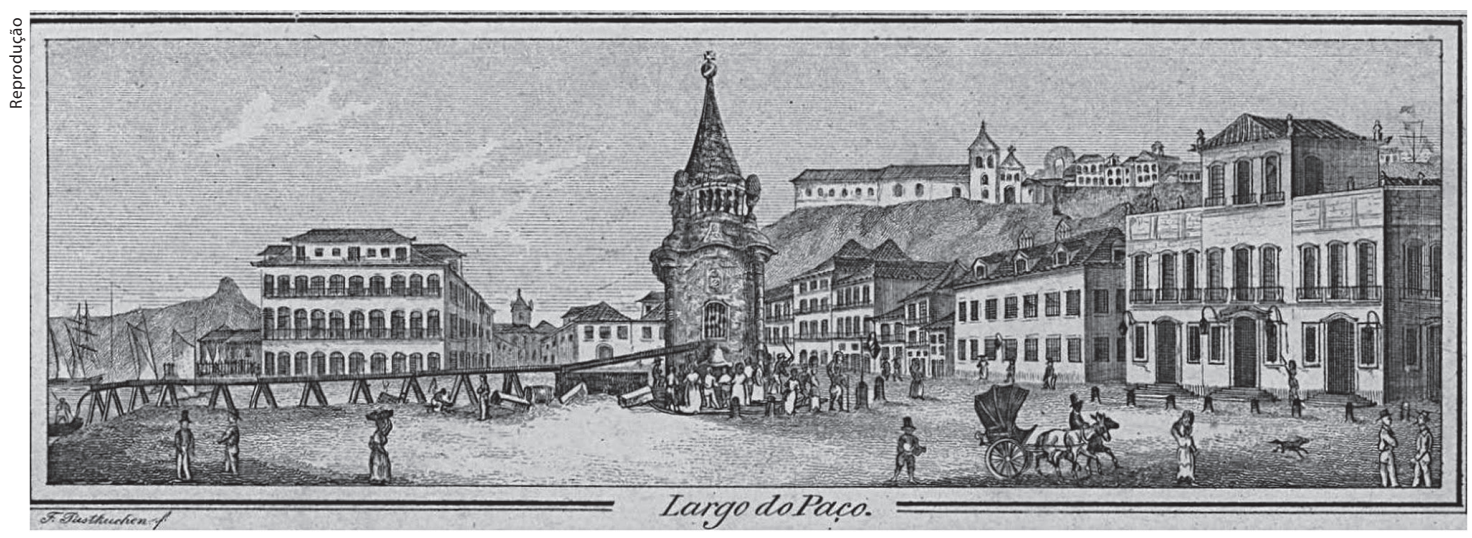

F. Pustkow, Largo do Paço (1844-1846), Vistas do Rio de Janeiro: Colecção Pustkow, Rio de Janeiro, G. Leuzinger, 1850, gravura. Acervo Biblioteca Nacional, RJ. Disponível em: http://objdigital.bn.br/ acervo_digital/div_iconografia/icon393034/icon393034_05.jpg.

e Smith, ou durante a permanência destes no Rio de Janeiro. É interessante observar que o telhado do canto esquerdo do palácio, onde se edificou a platibanda, parece ter estado em obras.

Devemos no referir também à série de vistas do Rio de Janeiro de autoria de Friedrich Pustkow, que datam presumivelmente de 1845-184655. As relativas ao Largo do Paço apresentam uma cuidadosa observação sobre as edificações do largo, especialmente as igrejas; nelas já se vê o palácio com as duas platibandas.

Ainda um dado fundamental sobre o conteúdo da imagem deve ser referido, e mais uma vez é o reverendo Kidder que vem em nosso auxílio ao afirmar, em seu livro Brazil and the Brazilians, que "a Bolsa ["Exchange"] não está longe da Alfândega, que antigamente tinha sua entrada principal adjacente à Praça”, descrição que se

55 As vistas desse artista foram publicadas em forma de álbum por Leuzinger, em 1850. confirma pela imagem do daguerreótipo em estudo. Uma placa fixada na fachada do casario que fazia esquina com a Rua Direita tem sido sistematicamente lida pelos pesquisadores como "Hotel de France" (sic). Na realidade trata-se de mais um erro que vem se repetindo há décadas. O que, de fato, estava lá escrito é "Exchange"56; não poderia ser "Hotel de France", pois este estabelecimento só seria inaugurado naquele local em maio de 1851 , como comprovamos antes.

Em função do que foi exposto ao longo deste texto, a datação e a autoria do daguerreótipo do Largo do Paço nos parecem estar agora consistentemente determinadas. Acreditamos que muitos dos equívocos e "mistérios" que rondavam a história desse daguerreótipo estejam finalmente esclarecidos.

56 À direita da palavra "Exchange", aparentemente se lê "14", que é a numeração do local que aparece muitas vezes nos anúncios. Kidder retornou aos EUA em maio de 1840; nessa data a placa referida já estaria fixada no local. 


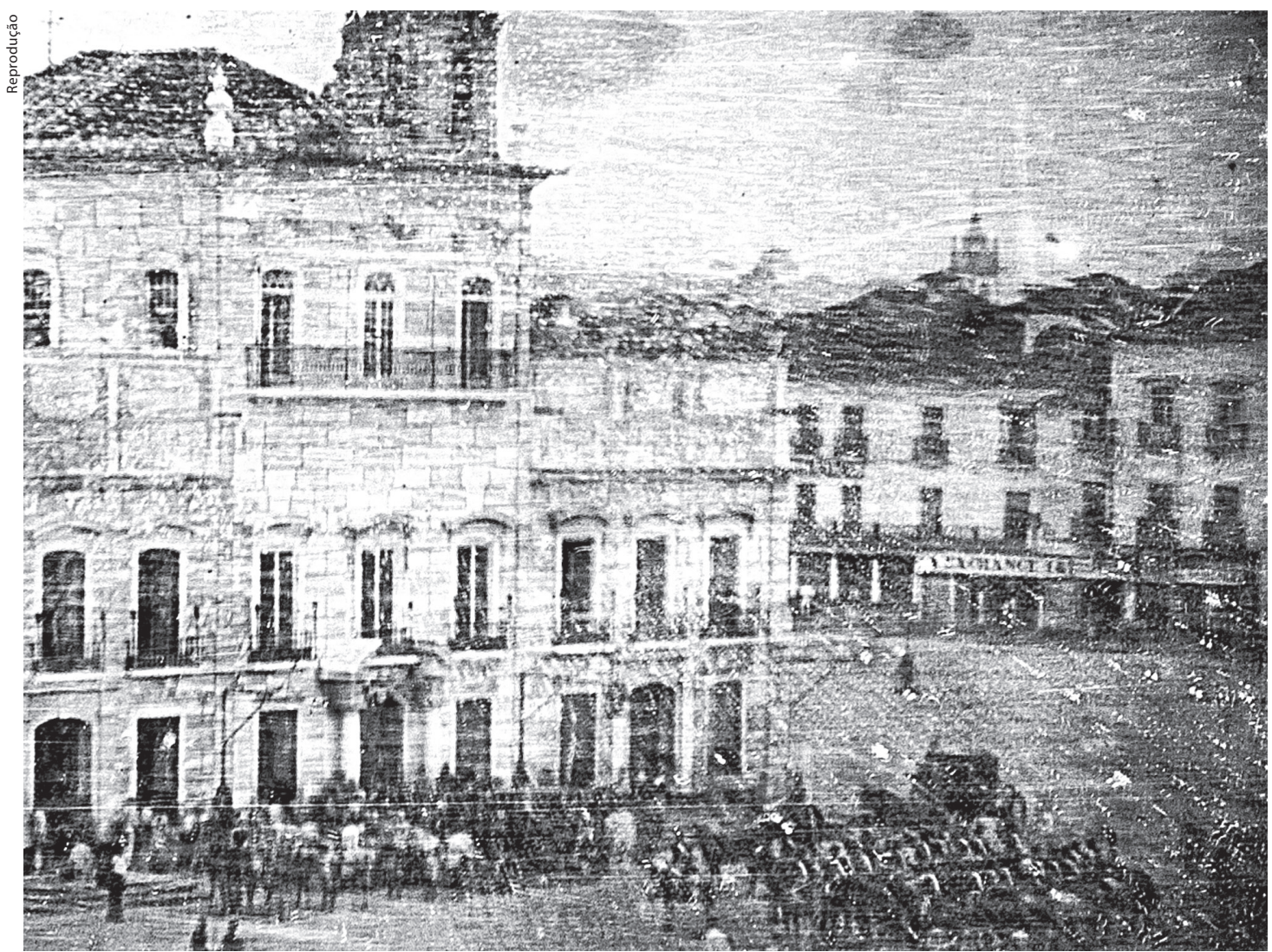

A. Morand e J. Smith. Detalhe ampliado da vista do Largo do Paço, onde se pode ler a placa publicitária “Exchange”, à direita, em um dos imóveis da família Telles

Quero manifestar meus melhores agradecimentos à historiadora Claudia Beatriz Heynemann, pela generosa colaboração desde os primeiros momentos em que me dediquei à elaboração desta pesquisa. Devo ao arquiteto André Luís de Lima a determinação dos ângulos das vistas e altura dos pontos de vista. Devo ao fotógrafo Zé de Boni a ideia e a execução da fusão de imagens, reprodução e ampliações, assim como indicações técnicas específicas acerca de câmeras, chapas e lentes. Agradeço a ambos e também ao fotógrafo e teórico Carlos Fadon Vicente, pelas indicações inteligentes e pelo tempo dispendido em longas e profícuas trocas de ideias. Agradeço ainda a Walter Pires, Susana Lourenço Marques, Suzana Gaspar de Oliveira Martins, Roger Hama Sassaki, Carol Colffield e Lunara Moreira, que, de diferentes formas, colaboraram comigo nesta empreitada. Meu especial agradecimento é devido a Maria Luiza Tucci Carneiro, minha companheira, pelas sugestões sensíveis e pelo encorajamento de sempre. A colaboração de todos foi decisiva para a realização desta pesquisa. 


\section{BIBLIOGRAFIA}

ADALBERTO, Henrique Guilherme [Príncipe da Prússia]. Brasil: Amazonas -Xingu. Tradução e notas de Eduardo Lima Castro. Belo Horizonte, Itatiaia/Edusp, 1977.

BALLHAUSE, Sylvia. The Munich Daguerre-Tryptich. From the exhibition "Images" by Sylvia Ballhause. Les Rencontres d'Arles, France, 2 July-19 August 2012. Disponível em: http://www.sylviaballhause.de/assets/Textdateien/Daguerre-folder safe.pdf?PHPSESSI $D=$ j1glkdmv6iv6a04gcv486m6ip4. Acesso em: 31/1/2019.

BROQUETAS, Magdalena (org.). Fotografía en Uruguay. Historia y usos sociales - 1840-1930. Montevidéu, Universidad de la República/CDMF, 2011.

CARVALHO, Augusto da Silva. "Subsídios para história da introdução da fotografia em Portugal", in Memórias da Academia das Ciências. Classe de Ciências. Lisboa, Academia das Ciências de Lisboa, 1939, tomo III, pp. 21-55.

DAGUERRE, L. J. M. et al. Historique et description des procédés du daguerréotype et du diorama / rédigés par Daguerre, ornés du portrait de l'auteur; et augmentés de notes et d'observations par MM. Lerebours et Susse frères. $1^{\text {a }}$ ed. Paris, Susse Frères, 1839. Disponível em: https://gallica.bnf.fr/ark:/12148/bpt6k56753837/f2.image.textelmage. EDER, Josef Maria. History of photography. New York, Dover, 1968.

ENCICLOPÉDIA Itaú Cultural de Arte e Cultura Brasileiras. Grandjean de Montigny. São Paulo, Itaú Cultural, 2018. Disponível em: http://enciclopedia.itaucultural.org.br/ pessoa214530/grandjean-de-montigny. Acesso em: 11/9/2018. Louis Buvelot. São Paulo, Itaú Cultural, 2018. Disponível em: http:// enciclopedia.itaucultural.org.br/pessoa23779/louis-buvelot. Acesso em: 10/8/2018. FARIA, Patrícia Souza de. Mestre Valentim. Rio de Janeiro, Biblioteca Nacional Digital, 2007. Disponível em: http://bndigital.bn.gov.br/mestre-valentim. Acesso em: 5/9/2018. FERREZ, Gilberto. "A fotografia no Brasil e um de seus mais dedicados servidores, Marc Ferrez", in Revista do Patrimônio Histórico e Artístico Nacional, n. 10. Rio de Janeiro, Ministério da Educação e Saúde, 1946.

A fotografia no Brasil - 1840-1900. Rio de Janeiro, Fundação Nacional de Arte/ Fundação Nacional Pró-Memória, 1985.

FERREZ, Gilberto; NAEF, Weston. Pioneer photographers of Brazil. New York, The Center for Inter-American Relations, 1976.

FLETCHER, James C.; KIDDER, Daniel Parish. Brazil and the Brazilians, Portrayed in Historical and Descriptive Sketches. Boston, Littel, Brown \& Co., 1879.

HISTÓRIAS E MONUMENTOS. Brasil: RJ: Rio de Janeiro. Hotel Pharoux. Disponível em: http://historiasemonumentos.blogspot.com/2015/05/brasil-rj-rio-de-janeirohotelpharoux.html. Acesso em: 10/9/2018.

KIDDER, Daniel Parish. "Augustus Morand the daguerrean art", in Photographic Art Journal, 1, 4. Nova York, 1851, pp. 237-9.

Reminiscências de viagens e permanência no Brasil. São Paulo, Martins, 1940.

KOSSOY, Boris. Dicionário histórico-fotográfico brasileiro. Fotógrafos e ofício da fotografia no Brasil (1833-1910). São Paulo, Instituto Moreira Salles, 2002.

"Reflexiones sobre la historia de la fotografia", in Joan Fontcuberta (org.).

Fotografia. Crisis de historia. Barcelona, Actar, 2003. 
Hercule Florence, a descoberta isolada da fotografia no Brasil. $3^{a}$ ed. revista e ampliada. São Paulo, Edusp, 2006.

LAGO, Pedro Corrêa do. "Fotógrafos estrangeiros do século XIX", in Nelson Aguilar (org.). Mostra do redescobrimento: o olhar distante. São Paulo, Fundação Bienal de São Paulo/ Associação Brasil 500 anos Artes Visuais, 2000, pp. 230-1.

MARQUES, Susana Lourenço. Fotografia-história, o pensamento em imagens. Tese de doutoramento. Lisboa, Faculdade de Ciências Sociais e Humanas, Nova FCSH, 2015.

MEMÓRIAS da Academia das Ciências de Lisboa. Classe de Ciências. Lisboa, Academia das Ciências de Lisboa, 1939, tomo III.

MOREIRA DE AZEVEDO. Rio de Janeiro, sua história, monumentos, homens notáveis, usos e curiosidades. Rio de Janeiro, Garnier, 1877.

NEWHALL, Beaumont. The daguerreotype in America. New York, Dover, 1975.

PÉNICHON, Sylvie. "The History of the Daguerreotype in Brazil", in Daguerreian Annual 2002-2003. Pittsburgh, The Daguerreian Society, 2004, pp. 317-31.

TURAZZI, Maria Inez. "Foco na viagem. Máquina viajante", in Revista de História da Biblioteca Nacional, ano 5, n. 52. Rio de Janeiro, Biblioteca Nacional, jan./2010, pp.18-24. Disponível em: http://www.revistadehistoria.com.br/v2/home/impressao. php?id=2850\&pagina=1. Acesso em: 3/12/2012.

VASQUEZ, Pedro. O Brasil na fotografia oitocentista. São Paulo, Metalivros, 2003.

WOOD, Rupert Derek. "A viagem do Capitão Lucas e do daguerreótipo a Sidney", tradução de Ricardo Mendes. Disponível em: www.fotoplus.com/fpb/fpb039/b039a. htm. Publicado originalmente no NZ Journal of Photography, (16), 3-7 agosto 1994. Disponível em: http://www.midley.co.uk/midley_pdfs/Lucas_Portuguese_notags.pdf. Acesso em: 5/8/2018. 